\title{
Controlling Parallel Exchange Market by Monetary Targeting and Anti-Inflationary Policies
}

\author{
Bijan Bidabad $^{1}$
}

\begin{abstract}
In this paper, the triangular relationship between money, price, and foreign exchange are studied. It is concluded that regulating the exchange rate by volume of liquidity in a period of less than a year is not possible, but in annual and biannual analyses, we can regulate the exchange rate through controlling the liquidity. In other words, in the long run, the exchange rate is affected by liquidity and price level, but in the short run, the price level has only temporary effects on the exchange rate. The results of the study show that:

- Liquidity affects the exchange rate in the long run

- Prices affect the liquidity in the long run

- In the long run, liquidity and exchange rate affect prices

Our results show that injection of foreign exchange into the parallel exchange market with different lags has little effects with different directions on the exchange rate. The same result is true for the relationship between liquidity and dollar rate. In other words, in spite of the long run relationship between exchange rate and liquidity, we cannot justify this relationship in the short run. The same is true with the balance of payments position and exchange rate in the short run.

By simulating the relationship between injecting (selling) foreign exchange in the parallel exchange market, liquidity and the cumulative balance of payments all with exchange rate, we can conclude that in the short run, regulating exchange rate by instruments such as selling exchange in the parallel market or controlling the liquidity is not possible, but in the long run, conducting foreign exchange sale policy and controlling the liquidity and the balance of payments position can control the exchange market.
\end{abstract}

Keywords: Foreign exchange, Money supply targeting, Monetary policy, Market control, Exchange rate policy

\section{Introduction}

Mixed monetary-exchange policy making is one of the important problems in macro-economic planning. If monetary and exchange policies are selected independently, one policy may neutralize the effects of the other, and other goals such as price stabilization may not be fulfilled. Therefore, selection of the mixed policies in this regard is one of the fundamental subjects in obtaining economic stabilization goals. For this reason, the present study will consider mixed policies of controlling liquidity and exchange rate for obtaining inflation control. Therefore, two major policies of monetary and exchange rate targeting are regarded as a base, and price stabilization policy is introduced from the mutual relationship of the two mixed policies.

Since usually for applying a policy, we have to use only one instrument, controlling the general level of prices by one policy variable faces difficulty from a mathematical point of view because this means to solve an equation with two unknowns. The solution for unknown variables is achieved through a combination of possible solutions. Keeping this in mind, and regarding that our policy variable in this discussion is liquidity which has a direct effect on both our targeted exchange rate and targeted inflation rate variables, therefore, obtaining one target, automatically achieves the other target; but the only remaining problem is the effect on the second target is not as much as we wished a priori. In other words, it means that if liquidity decreases A percent, the decrease in the exchange rate and the inflation rate will be $\mathrm{B}$ percent and $\mathrm{C}$ percent respectively. Therefore, in order to reach target $\mathrm{B}$, we can use the variable $\mathrm{A}$, but the figure for $\mathrm{C}$ will be obligatory (automatically) defined. But since the targets

${ }^{1}$ (B.A., M.Sc., Ph.D., Post-Doc.) Research Professor of Economics, Monetary and Banking Research Academy, bidabad@yahoo.com bijan@bidabad.com http://www.bidabad.com. 
have the same direction, reaching B is accompanied by somehow of reaching target C, which is not as much as the policymaker intended.

In order to obtain predefined amounts for B and C, the policy variables should be increased to two. This means that we have to change simultaneously the two variables of liquidity and foreign exchange supply in order to control the two variables of the value of the national currency (exchange rate) and inflation rate. In this case, the number of instrumental variables is equal to the number of target variables, and the problem has a solution from a mathematical point of view. Therefore, we select two main lines for our study, which are practically based upon our two target variables. These two axes are as follows:

- Inflation targeting policies

- Exchange rate targeting policies

Several surveys have been carried out about inflation targeting, and this policy is regarded as a recognized method for controlling inflation. The basis of this policy is using monetary instruments to control liquidity in order to achieve an optimum rate of inflation. The abstract of these concepts is presented by a joint paper of M. Mojarrad and B. Bidabad in 1997. There are many documented guidelines about targeting the exchange rate, which is described in the collection of trade and exchange rate policies of governments and central banks around the world for controlling the supply of foreign exchange. They are all somehow connected to the supply of foreign exchange, but in this paper, we will only consider the direct interference of the central bank as an instrument of foreign exchange supply control.

\section{Inflation targeting and monetary policy in Iran (IR)}

There are many discussions between economists about inflation with the meaning of a rapid and sustained increase in prices from its reasons and sources, its economic importance, its control and its effects on other economic variables points of view, which are not mentioned in this paper. There are also many studies in Iran about inflation, its causes, and effects. Most of these studies confirm that inflation in Iran is a monetary phenomenon, and other factors such as those concerning supply side, or cost-push inflation have fewer effects on the increase of general price level. More explicitly, we can say that although inflation sources of supply-side have had short-run effects on prices, in the long run, inflation in Iran has been demand pull ${ }^{2}$. On the basis of many studies, we can conclude that about $99 \%$ of long-run price changes were caused by the increase in liquidity. In other words, they confirm the monetary nature of inflation in the country and consider the control of liquidity as the only way for controlling inflation. Regarding different studies conducted in Iran, we realize that Monetary Transmission Mechanism which is the affecting method of monetary policy and liquidity on the real sector of the economy which almost has had no effects, because it couldn't create any motivation through decreasing the rate of interest of banking loans. In other words, liquidity can only affect the demand through price increases. This notion opens the way for Iran's policymakers in targeting inflation via controlling the liquidity without worrying about the depression of the supply side. In other words, now we can claim that the decrease in liquidity will not cause production decrease. It is clear that all these concepts are considered in the domain of long term analyses.

Before recent five years plans, we practically didn't have any targeting policy as in comparison with other countries for controlling the inflation but during first and second development plans of 1989-93 and 1995-1999; we observe some targeting for controlling the inflation. These targeting in the text of the plan's aims are specified as a defined rate of inflation as a target.

We have some similarities with other countries in targeting. In general, the practices of other countries show that the targeting plan for controlling inflation is in the medium term framework. Regarding the goals of the first and second development plan, we see similar policies for medium-term goals. The second plan, which was arranged on the bases of the stability of internal and external sectors from the stability of prices and balance of payments points of view, had a target rate of $12.4 \%$ for the annual inflation rate. Of course, regarding the special position of our country from a dependency point of view on oil income and oil shocks and various international problems, it seems that if

2 - Komijani and Bidabad, 1990, 1991 and 1992. http://www.bidabad.com/ 
this goal was set in a range which could cover the effects of foreign fluctuations, it would increase the credibility of targeting for controlling the inflation. In this regard, we can mention the deep affectability of monetary policy from fiscal policy and considering the experience of other countries for controlling inflation; this concept will be very important.

In the third development plan, the views of the planners on economic problems were changed in general, and therefore, they didn't use classic methods for planning in determining quantitative goals. That is why we can't perceive their views on inflation targeting. The third plan was in general concerned about structural reforms and did not discuss the details of quantitative goals.

Considering all above concepts, there is also another important principle in other countries which is considered as the reason for their success, and it is credibility, acceptability and the belief of private sector about targeting policies for controlling inflation for which unfortunately no important step has been taken about this concept in Iran. The other problem is the responsiveness of the monetary authorities to defined goals. It seems that the central bank should not surpass its legal authorities. Surpassing credit ceilings reduces the responsiveness of the central bank to the concerned authorities. Keeping these ceilings in other countries is strictly regarded by policymakers of other countries. If the central bank pursuit only ad hoc and day-to-day policies, it cannot achieve the predefined goals.

It is also clear that in order to a complete success in conducting monetary policies, necessary conditions should be available so that all monetary tools could be used. The study of previous conditions and backgrounds shows that the central bank could not use some of her legal monetary instruments effectively. These include open market operations, discount window, reserve requirement ratio, and the interest rates of bank loans and credits. All these instruments could not be used thoroughly or partially because of their own reasons.

\section{Exchange rate targeting policy}

As it was mentioned, all policies that are to somehow related to exchange rate control can be related to exchange rate targeting, and most of the economic policies are to somehow related to foreign exchange. But at this moment, we are focused on the supply of foreign exchange for controlling the exchange rate. The generality of this discussion is prevailing in exchange rate management policies, but here we only study the open market policy conducted on foreign exchange by monetary authorities in the parallel market. This policy is called "sale of foreign exchange in the parallel (free) market" and was adopted for the period of 1989 to 2001.

In general, it is clear that whenever governments try to control prices through non-economic measures which are in confliction with supply and demand mechanism, automatically a parallel market is developed. The emergence of the parallel exchange market in the previous two decades is not exempted from this general rule. Governments consider parallel markets as an obstacle for implementing their policies, but we should accept that parallel markets are the results of the government policies. In other words, whenever we do not follow the inherent rules of economics, we should be waiting for the emergence parallel market in the same field of policymaking.

Before the revolution, the foreign exchange parallel market was negligible. Very few amounts of foreign exchange were transacted in exchange offices at a price which followed the exchange rate of the banking system, so these exchange offices pegged their rates between of bid and offer rates of the banking rates. In other words, their bid rate was a little more than the bid rate of the banking system, and their offer rate was a little lower than the banking offer rates. This method of pricing helped them to survive; in other words, their profit margin was between the profit margins of the banks. After the revolution, banks developed regulations on exchange sale, which was considered as a restriction for the supply of foreign exchange. The restricted supply practically pushed up the rates, but the government kept banking rates unchanged, which caused to develop a parallel market with higher rates. Because of the unordinary conditions of post-revolution, the gap between the parallel market and banking rates widened. The government tried several times to control this market with new regulations. The extent of these regulations went so far to consider the dealers of the parallel market as trouble-makers, or economic terrorists and heavy penalties were developed for them, and police and security forces were used against this market, but the government had little success in eliminating this market. 
One of the policies applied against this market was government interference in the market by direct sale of foreign exchange in order to increase the supply and decrease the parallel rates. This policy was conducted in several ways so that the banking system also sold foreign exchange with special rates and conditions. Sometimes the central bank gave official permissions to private foreign exchange offices and sold foreign exchange through these offices. In some exceptional cases, the brokers of the central bank sold foreign exchange on the nearby main streets. These decisions were made on the bases of the analysis of the decision makers of those days, but the main principle behind these decisions was injecting foreign exchange into the market in order to decrease the parallel rates and achieve income in Rial terms.

The main precondition for applying this policy is the acceptance of an unofficial foreign exchange market. In some years, the policymakers were so radical that they considered the dealers of the parallel market as smugglers and punished them very severely, which suggests that this policy was not developed very well. We should accept that during the scarcity of foreign exchange supply with fixed rate regime, this is a natural phenomenon, and the market mechanism creates it automatically. The best method of dealing with this market is accepting it for the first time. This means that we should legally accept the transactions through this market and even consider it as an economic activity and prevent any noise from it and in the next phase automatically try to marginalize it by applying policies and adopting reforms in foreign exchange management. If the foreign exchange system tends to unify, the management of the system becomes transparent. In other words, all transactions of goods and services should be done in single rates, and the rate of the parallel market will, at last, be within the margins of official rate fluctuations.

Since the prices of many items of goods and services are affected by the foreign exchange rate in the parallel market and its fluctuations will cause the fluctuation of the prices of goods and services, the stabilization of the foreign exchange rate in the parallel market will cause partial stabilization in goods and services market. The injections of foreign exchange into the parallel market for stabilization will spill over into other markets.

After the revolution in Iran, the volume of money in circulation has had an increasing trend. Economic theories demonstrate that this increase will lead to depreciation of money, in other words, when the volume of Rial is increased, we should expect that the value of Rial is to be reduced against foreign currencies, or its parity rate decreases. We have practically seen this event in the past few decades. The increase of the volume of Rial from 2613 billion in 1996 to 320957 billion Rials at the end of 2001 can be the main cause of the increase of parity rate of American Dollar from 70 Rials to 8000 Rials. Econometric researches also confirm this finding.

The policy of selling foreign exchange in the parallel market not only increases the supply of foreign exchange but also decreases the amount Rial in the market, both of which will strengthen the national currency. Most of the increases of the amount of liquidity after the revolution have been the result of the expansion of monetary base through the increases of government sector debts to the banking system. The details of this phenomenon have been described in several pieces of research, but here we consider that the mentioned results are sufficient to be used and not to be retested. The increase of the government sector's debt to the banking system has been created through financing budget deficit by borrowing from the banking system, which is similar to seignorage of extra money by expanding the monetary base. The policy of selling foreign exchange in the parallel market can be regarded as a method for partially financing the budget deficit. In this way, the government can finance the budget deficit by selling foreign exchange in the parallel market at unofficial prices without obligation of borrowing from the banking system. In other words, without increasing the liquidity (in spite of borrowing from the banking system), this policy can finance the budget deficit.

Price increase and inflation in Iran has a monetary source. Many studies confirm this hypothesis. The increase in money supply causes an increase in general price level instead of increasing the supply of goods and services in the economy. Regarding this concept, it could be said that the policy of selling foreign exchange in the parallel market will decrease the price level through the decreasing foreign exchange rate which causes to decrease the price of imported commodities which use foreign exchange from the parallel market sources, and also through decrease of liquidity which has a deflationary effect.

After the approval of the Usury-Free Banking Law, since bond has usuric nature, it cannot be applied as a policy tool for changing the amount of money in circulation. In the western economies, central banks conduct open market 
operations by buying and selling bonds, and decrease or increase the amount of money in circulation and thereby, affect the interest rates and investment thereafter. But as it was mentioned earlier, since it is not possible to use bonds, it is not possible to conduct open market operations. The government interference in the parallel exchange market affects liquidity, and if the government buys, as well as selling foreign exchange in this market, these activities will be more similar with open market operations, and therefore, it is possible to affect interest rate in the parallel market by applying this policy. Of course, this kind of operation is not completely in accordance with open market operation, but when other monetary instruments are not efficient enough, or applicable, this policy is of great help to monetary authorities.

After this explanation, we return to the policy of selling foreign exchange in the parallel market. This policy confirms the followings:

- The parallel market is implicitly accepted

- It is a step towards exchange rate unification

- It helps to stabilize the rates of foreign exchange

- It decreases the amount of available Rial, and thereof strengthens the national currency

- It can partially finance the budget deficit

- This policy has deflationary effects

- It can be regarded as a monetary tool for open market operations

\begin{tabular}{rr}
\hline Year & $\begin{array}{r}\text { sale of foreign exchange in the } \\
\text { parallel market (Billion Rials) }\end{array}$ \\
\hline 1982 & 0.00 \\
\hline 1983 & 5.70 \\
\hline 1984 & 34.50 \\
\hline 1985 & 88.70 \\
\hline 1986 & 17.90 \\
\hline 1987 & 87.00 \\
\hline 1988 & 141.50 \\
\hline 1989 & 744.30 \\
\hline 1990 & 2256.80 \\
\hline 1991 & 2510.70 \\
\hline 1992 & 4078.00 \\
\hline 1993 & 4775.00 \\
\hline 1994 & 0.00 \\
\hline 1995 & 2765.00 \\
\hline 1996 & 5407.00 \\
\hline 1997 & 10428.70 \\
\hline 1998 & 6021.90 \\
\hline 1999 & 18532.20 \\
\hline 2000 & 39323.50 \\
\hline 2001 & 52445.10 \\
\hline
\end{tabular}

The table above shows the amount of foreign exchange sold in the parallel market from 1982 to 2001 . Since the Central Bank has sold foreign exchange at different rates during this period, we have only the amounts in Rial term (not in Dollars). 
In the macro-econometric model of $\operatorname{Iran}^{3}$, the effect of selling foreign exchange in the parallel market has been studied. The calculations show that by selling foreign exchange equal to one thousand billion Rials, the exchange rate of the parallel market decline will be 65 Rials.

\section{The relationship between the exchange rate in the parallel market and liquidity}

Perhaps the most important and famous view about the method of defining the parity of exchange rate is to consider it as a price which is defined by the intersection of supply and demand of foreign exchange in the market. This view is regarded as the view of the balance of payments for determining the exchange rate because the supply and demand of foreign exchange is created through the transactions registered in the balance of payments. Balance of payments has two main different parts of current account and capital account. The current account includes the difference between imports and exports of goods and services and the net value of other received and payments such as compensations, gifts and etc. in connection with foreigners. If in this account imports exceed exports, it is said that the account is facing a deficit and vice versa. It is clear that this account is not necessarily always in balance. If this account is facing a deficit, it will be compensated by other accounts. This deficit means that the expenses abroad have been more than earnings from abroad.

One way of compensating this deficit is by the use of the capital account. In other words, this deficit will be deducted from the existing capital, or some amount of capital equal with the deficit has been transferred out of the country, so that brings the balance of payments to the equilibrium position. If there are no other transactions in the capital account, in order to keep the balance of payments, we have to import foreign capital as much as a deficit in the form of foreign loans, or the decrease of foreign exchange reserves or investment permissions to foreigners, etc. In other words, if a country faces a deficit in the balance of payments, it means that the reserves and assets of the country have been decreased. The monetary view of the balance of payments with emphasize on capital account practically defines the role of the balance of payments in determining the exchange rate. In simpler words, this view says that when the balance of payments is facing a deficit, the foreign assets will decrease equally. The importers go to the foreign exchange market according to their previous demand function, but since the supply of foreign exchange has been decreased as much as the deficit of balance of payments, the exchange rate increases. This increases the price of imported goods and therefore, decreases the demand for import; moreover, since export has become more profitable, exports will increase and leads to a new balance of payments and new exchange rate.

Here, the important thing is the amount of demand for import and the supply of export which specify this mechanism. Both of these functions are the result of domestic and external prices. In other words, whenever external prices do not change, and internal prices increase, the demand for import increases, and the supply for export decreases. These changes in import and export, through changes in the balance of payments and changes in the amount of foreign reserves, will cause changes in the foreign exchange rate. In other words, when domestic prices increase, the purchasing power decreases, but the demand for imported goods increases in comparison with domestic goods, which has now a higher price. Practically this situation causes an increase in the foreign exchange rate. An increase in the supply of national money has also a similar effect on the demand for the foreign exchange rate in the same way. The increase in national money supply will increase gross domestic expenditures, and domestic prices and the demand for imported goods will increase, and exports will decrease. Because as it was mentioned before, the demand for imports and the supply of exports are functions of domestic and external prices. The increase in demand for imports and the decline in the supply of exports will lead to a balance of payments deficit, which means an increase in demand for foreign currency because of the import increase. The interaction between the national currency and foreign exchange in the market for exchanging national money into the foreign exchange will ultimately lead to the increase of foreign exchange rate. In the second round, this increase will lead to the adjustment of the balance of payments and with higher prices and a higher rate of foreign exchange; a new equilibrium will be achieved in the economy. This phenomenon has been prevailing in the economy of Iran after the revolution. The permanent increase in the money supply has practically increased domestic prices and has decreased the purchasing power and caused the devaluation of the national currency. Several pieces of research confirm this phenomenon ${ }^{4}$.

3 - Bidabad, 1996. http://www.bidabad.com/

4 - Komijani and Bidabad, 1990, 1991, and 1992. http://www.bidabad.com/ 
There are also several papers showing that the permanent increase in the supply of money has caused the slow to lose the value of the national currency ${ }^{5}$. In these papers, an econometric model for Iran has been evaluated, and this hypothesis has been tested. Unfortunately, because of poor data available about the balance of payments, testing this hypothesis faces difficulties. Some of the problems of the balance of payments data have been described in annual economic reports of the Central Bank and papers written by the author in 1994 and 1995. In the research carried out by the author and Komijani (1992), the relationship of Dollar rate in the parallel market and balance of payments has been shown through econometric models. These researches show the strong descriptive effect of the balance of payments variable on the variations of the foreign exchange rate in the parallel market. But in spite of these confirmations, because of data problems of the balance of payments, the calculation results are very sensitive to every single year data, and by increasing or decreasing a single observation, the results of calculations will change very much.

In the continuation of the above-mentioned researches about the testing this hypothesis whether the continuous increase in the parity rate of Dollar with Rial in the parallel market is because of the increase of liquidity, various calculations have been carried out ${ }^{6}$. This calculation shows that by an increase of one trillion Rial of liquidity, the exchange rate in the parallel market increases 37.5 Rials. The results of the regression of this calculation describe 96 percent of the variations. That is to say, that 96 percent of the changes in the foreign exchange rate in the parallel market is due to the increase in liquidity.

Sometimes, economic analysts doubt that the increase of foreign exchange rate is the cause of the increase in liquidity and prices. In this regard, they believe that external shocks in the foreign exchange revenues are practically the reason for this increase, or the devaluation policy of the government has increased liquidity and prices.

In order to check the direction of causality, we conduct the following test. The aim of this test is first to find out whether the increase in the foreign exchange rate has caused an increase in liquidity? Secondly, is it true that the increase in the foreign exchange rate has caused prices to increase? In other words, which one is the cause and which one is the effect? To do this, Granger-Sims causality test has been carried out on monthly data. First, we test the causality of liquidity and the rate of foreign exchange in the parallel market. Then we test the causality of liquidity and price level. This shows that price level is not the main reason for the increase of liquidity, while, the increase of liquidity is the main source of the general price increase.

In short, from the above discussions, we conclude that the increase of liquidity not only increases the price level in Iran but also has caused an increase in the foreign exchange rate. In other words, the increase of liquidity in the country is the cause of decreasing the purchasing power of the national currency, and the decrease of parity rate of Rial against foreign exchanges. Therefore, the only way for stabilizing exchange rate is the controlling of liquidity. Otherwise, other temporary policies such as those conducted in the previous two decades, are not considered proper policies, because although those policies could have positive effects on the market, in the long run, will ruin the infrastructure for investment ${ }^{7}$. Therefore, considering the above discussions, the foreign exchange market should be controlled through mixed exchange and monetary policies.

\section{Time series analysis}

In this section, we test the time series for stationarity, to be used in the next sections. The following variables have been tested for unit root. All data are monthly series. Several tests such as $\mathrm{DF}^{8}$ and $\mathrm{ADF}^{9}$ have been used, and by using correlogram, auto-correlation, and partial correlation, the necessary differences were extracted to make the series stationary. Tests have been carried out on the followings variables:

- Foreign Exchange Rate

- Consumer Price Index

5 - Komijani and Bidabad, 1992, and Bidabad, 1994. http://www.bidabad.com/

6 - Bidabad, 1994. http://www.bidabad.com/

7 - Economic security and obstacles facing investment (Bidabad, 1995). http://www.bidabad.com/

8 - Dickey-Fuller.

9 - Augmented Dickey-Fuller. 
- $\quad$ liquidity (the broad definition of money $\mathrm{M}_{2}$ )

According to the studies, the following table has been prepared which shows the changes for making the stationery of the variables

\section{Variable}

Exchange rate [D(DOLLAR)]

Consumer price index $[\mathrm{D}(\mathrm{CPI})]$

\section{Changes made to make the series stationary}

First order difference

First order difference

Liquidity DLOGM $\mathrm{D}_{212}=\mathrm{D}\left(\log \left(\mathrm{M}_{2}\right), 1,12\right) \quad$ First order difference and 12 months difference on logarithm

After doing changes to make the series stationary, we concluded that:

- The logarithm of most of the series increases stationarity

- Some monetary series and prices needed 12 months difference

- Therefore, the following variables can be regarded as I(1) variables

- $\mathrm{D}(\log ($ Dollar $),, 12)$

- $\mathrm{D}(\log (\mathrm{CPI}),, 12)$

- $\mathrm{D}\left(\log \left(\mathrm{M}_{2}\right),, 12\right)$

\section{Causality between the main variables}

The previous studies and the assumptions of the present study are based on the tight relationship between monetary variables, foreign exchange rate, and prices. In this section, we use causality tests on these variables. In other words, we want to test the direction of the effect on the foreign exchange rate by the monetary variable and general price level.

By the previous section, we found out the different orders to make the necessary time series stationary. Now we use these results. Before evaluating the causality between the variables, in order to find the correct form of Granger relationship, we have to check for their co-integration.

If the residual of long term regression of the two variables are stationary, or in other words, they have not a unit root, the two variables are co-integrated. If so, their simple difference will not be enough for regression, and therefore, the model should be used as $\mathrm{ECM}^{10}$. Although this correction can explain the short variations of the model around the long term trend by inserting an error item which has been obtained from the long run equation, it adds its own problems to the model. For example, if the specification of the model is not strictly supported by economic theory, the results of the Error Correction Model will have conceptual problems.

\section{Theoretical dynamic causality among variables}

When we define a regression, we implicitly presuppose that what variable or variables explain another variable which is defined as the dependent variable. It means that we define the causality relationship in which, by changing a variable, the dependent variable will change. This causality relationship can be a one-way relationship or two ways. If $\mathrm{X}$ causes $\mathrm{Y}$, but $\mathrm{Y}$ has no effect on $\mathrm{X}$, it is a one-way relationship. But if $\mathrm{X}$ affects $\mathrm{Y}$, and $\mathrm{Y}$ affects $\mathrm{X}$, then we have a two-ways or polar relationship. One of the methods for the causality test is the Granger test. This test is based on this concept that the future can not affect the past or the present time. The test is a kind of VAR(k) test:

$$
\begin{aligned}
& Y_{t}=\alpha_{10}+\sum_{i=1}^{k} a_{i j} X_{t-j}+\sum_{j=1}^{k} \beta_{1 j} Y_{t-j}+e_{1 t} \\
& X_{t}=\alpha_{20}+\sum_{j=1}^{X} a_{2 j} X_{t-j}+\sum_{j=1}^{K} \beta_{2 j} Y_{t-j}+e_{2 t}
\end{aligned}
$$

10 - Error Correction Model. 
Upon the above equations, we can evaluate the following different cases:

1. If $\left\{\alpha_{11}, \alpha_{12}, \ldots, \alpha_{1 k}\right\} \neq 0$ and $\left\{\beta_{21}, \beta_{22}, \ldots, \beta_{2 k}\right\}=0$, there is a one-way causality relationship from $\mathrm{X}$ to $\mathrm{Y}$.

2. If $\left\{\alpha_{11}, \alpha_{12}, \ldots, \alpha_{1 k}\right\}=0$ and $\left\{\beta_{21}, \beta_{22}, \ldots, \beta_{2 k}\right\} \neq 0$, there is a one-way causality relationship from $\mathrm{Y}$ to $\mathrm{X}$.

3. If $\left\{\alpha_{11}, \alpha_{12}, \ldots, \alpha_{1 k}\right\} \neq 0$ and $\left\{\beta_{21}, \beta_{22}, \ldots, \beta_{2 k}\right\} \neq 0$, there is a two ways causality relationship between $\mathrm{Y}$ and $\mathrm{X}$.

In order to test the above hypothesis, we use F statistics. This test will be carried out after testing for stationarity and making variables stationary before further use.

\section{The dynamic causality among variables (practical)}

Regarding the mentioned cases in the previous section, by using the Granger causality test, we test the variables two by two and with different lags. The first group of tests includes testing causality among three variables in a range of 1 to 24 lags:

- The first order difference of Dollar rate series with 12 months seasonal adjustment (ddollar)

- The first order difference of liquidity with 12 months of seasonal adjustment $(\mathrm{dm} 2112)$

- The first order difference of consumer price index with 12 months seasonal adjustment (dcpi112)

The second group of tests is similar to the first group with one difference that the logarithms of variables are used instead of the original ones.

The summary of the results of these tests is presented in the next tables and diagrams. The table of $\mathrm{F}$ statistics defines the probability of accepting the null hypothesis. This hypothesis is defined as follows:

$\mathrm{H}_{0}$ : The variable one is not the cause of the second variable.

$\mathrm{H}_{1}$ : The variable one is the cause of the second variable.

If the calculated $\mathrm{F}$ is greater than $\mathrm{F}$ in the table, we reject the null hypothesis, and if the calculated $\mathrm{F}$ is smaller than $\mathrm{F}$ in the table, we accept the null hypothesis.

The following table gives $\mathrm{F}$ statistics for a large number of observations (more than 120 in this case) and the degree of freedom of the denominator equal to 5 percent and 1 percent level of significance:

F statistics for a number of observations over 120 and degree of freedom of numerator (lag)

\begin{tabular}{|c|c|c|c|c|c|c|c|c|c|c|c|c|c|c|}
\hline Lags & 1 & 2 & 3 & 4 & 5 & 6 & 7 & 8 & 9 & 10 & 12 & 15 & 20 & 24 \\
\hline $\begin{array}{l}5 \% \text { level of } \\
\text { significance } \mathrm{F}\end{array}$ & 3.84 & 3.00 & 2.60 & 2.37 & 2.21 & 2.10 & 2.01 & 1.94 & 1.88 & 1.83 & 1.75 & 1.67 & 1.57 & 1.52 \\
\hline $\begin{array}{l}1 \% \text { level of } \\
\text { significance } \mathrm{F}\end{array}$ & 6.63 & 4.61 & 3.78 & 3.32 & 3.02 & 2.80 & 2.64 & 2.51 & 2.41 & 2.32 & 2.18 & 2.04 & 1.88 & 1.79 \\
\hline
\end{tabular}

By considering the next tables and the graphs for a simple non-logarithmic model, we conclude:

- The change in Dollar rate, after at least 1 month, will lead to a change in liquidity.

- The change in liquidity will affect Dollar rate after 1 month, and its further effects appear after 9 to 11 months and again after 2 years changes the Dollar rate.

- Changes in prices affect liquidity after a lag of 8 months to 2 years.

- Liquidity changes will affect prices after 1 year. 
- $\quad$ Price changes affect the Dollar rate after 1 month.

- Changes in Dollar rate affect CPI in every lag.

In short, with the analysis of the above conclusions, at $95 \%$ of significance level, we can draw the following diagram:

With 3 to 5 months lag
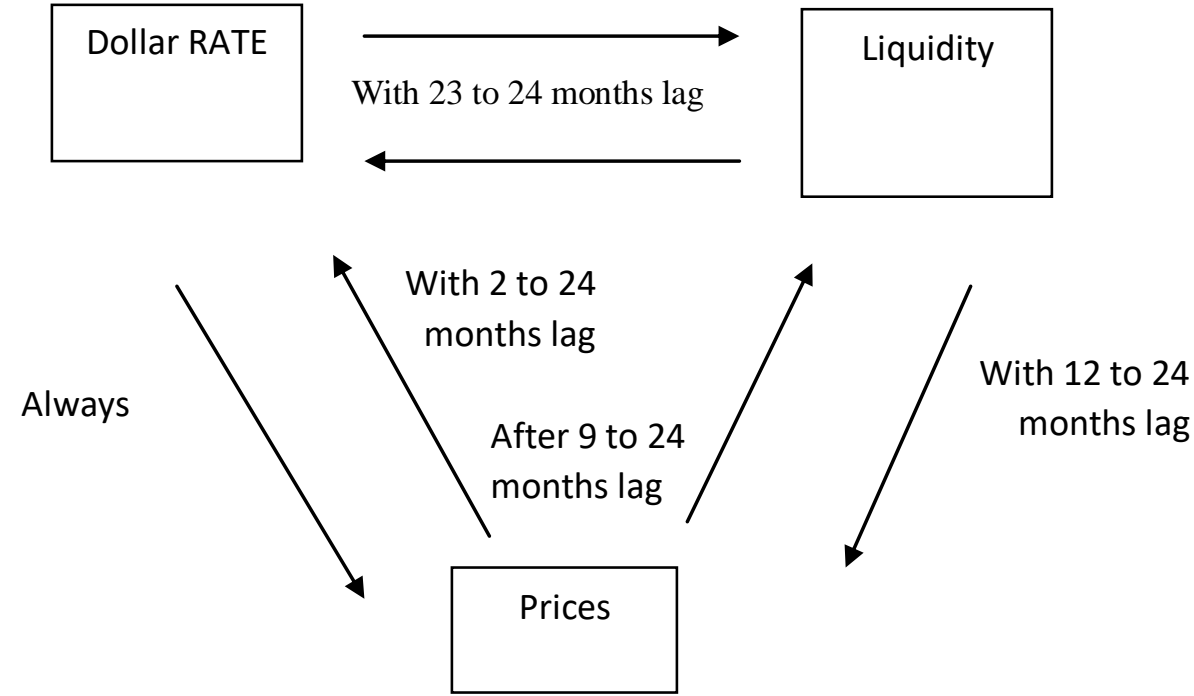

\begin{tabular}{|c|c|c|c|c|c|c|}
\hline \multirow{2}{*}{$\begin{array}{c}\text { Simple } \\
\text { Number } \\
\text { of Lags }\end{array}$} & \multicolumn{6}{|c|}{ F-Statistics } \\
\hline & $\begin{array}{c}\text { ddollar112 } \\
\text { does not } \\
\text { Granger } \\
\text { cause } \\
\text { dm2112 }\end{array}$ & $\begin{array}{c}\operatorname{dm} 2112 \\
\text { does not } \\
\text { Granger } \\
\text { cause } \\
\text { ddollar112 }\end{array}$ & $\begin{array}{c}\text { dcpi112 } \\
\text { does not } \\
\text { Granger } \\
\text { cause } \\
\text { dm2112 }\end{array}$ & $\begin{array}{c}\text { dm2112 } \\
\text { does not } \\
\text { Granger } \\
\text { cause } \\
\text { dcpi112 }\end{array}$ & $\begin{array}{c}\text { dcpi112 } \\
\text { does not } \\
\text { Granger } \\
\text { cause } \\
\text { ddollar112 }\end{array}$ & $\begin{array}{c}\text { ddollar112 } \\
\text { does not } \\
\text { Granger } \\
\text { cause } \\
\text { dcpi112 }\end{array}$ \\
\hline 1 & 2.754 & 3.292 & 0.148 & 0.250 & 2.257 & 6.882 \\
\hline 2 & 3.980 & 1.220 & 0.268 & 0.784 & 8.270 & 4.553 \\
\hline 3 & 6.872 & 1.444 & 0.071 & 0.459 & 5.796 & 2.950 \\
\hline 4 & 5.729 & 0.857 & 0.868 & 0.356 & 4.901 & 3.784 \\
\hline 5 & 4.883 & 1.116 & 1.408 & 1.157 & 6.056 & 3.440 \\
\hline 6 & 4.091 & 1.626 & 1.285 & 1.291 & 5.095 & 3.334 \\
\hline 7 & 4.776 & 1.379 & 1.302 & 1.267 & 5.383 & 4.325 \\
\hline 8 & 4.221 & 1.150 & 1.347 & 0.961 & 5.225 & 3.775 \\
\hline 9 & 4.345 & 1.780 & 3.038 & 0.930 & 4.265 & 4.127 \\
\hline 10 & 4.244 & 1.747 & 2.715 & 0.818 & 3.790 & 3.657 \\
\hline 11 & 3.918 & 1.649 & 2.496 & 1.175 & 3.367 & 4.448 \\
\hline 12 & 3.700 & 0.742 & 2.176 & 1.859 & 2.456 & 2.577 \\
\hline 13 & 3.403 & 0.694 & 2.137 & 1.863 & 2.335 & 2.509 \\
\hline 14 & 3.157 & 0.671 & 2.036 & 2.014 & 2.473 & 2.339 \\
\hline 15 & 2.780 & 0.637 & 2.075 & 1.739 & 2.198 & 2.622 \\
\hline 16 & 2.541 & 0.696 & 2.173 & 1.959 & 2.232 & 2.250 \\
\hline 17 & 2.505 & 0.715 & 2.197 & 1.849 & 2.107 & 2.102 \\
\hline
\end{tabular}




\begin{tabular}{lllllll}
\hline $\mathbf{1 8}$ & 2.345 & 0.801 & 2.433 & 1.815 & 2.227 & 2.057 \\
\hline $\mathbf{1 9}$ & 2.294 & 0.943 & 2.546 & 1.699 & 2.095 & 1.992 \\
\hline $\mathbf{2 0}$ & 2.320 & 1.097 & 2.382 & 1.558 & 1.998 & 1.852 \\
\hline $\mathbf{2 1}$ & 2.419 & 1.050 & 1.997 & 1.629 & 2.063 & 1.866 \\
\hline $\mathbf{2 2}$ & 2.753 & 1.142 & 1.801 & 1.628 & 2.185 & 1.907 \\
\hline $\mathbf{2 3}$ & 2.500 & 1.620 & 1.732 & 1.640 & 2.190 & 1.862 \\
\hline $\mathbf{2 4}$ & 2.363 & 1.633 & 1.634 & 1.697 & 1.591 & 1.597 \\
\hline
\end{tabular}

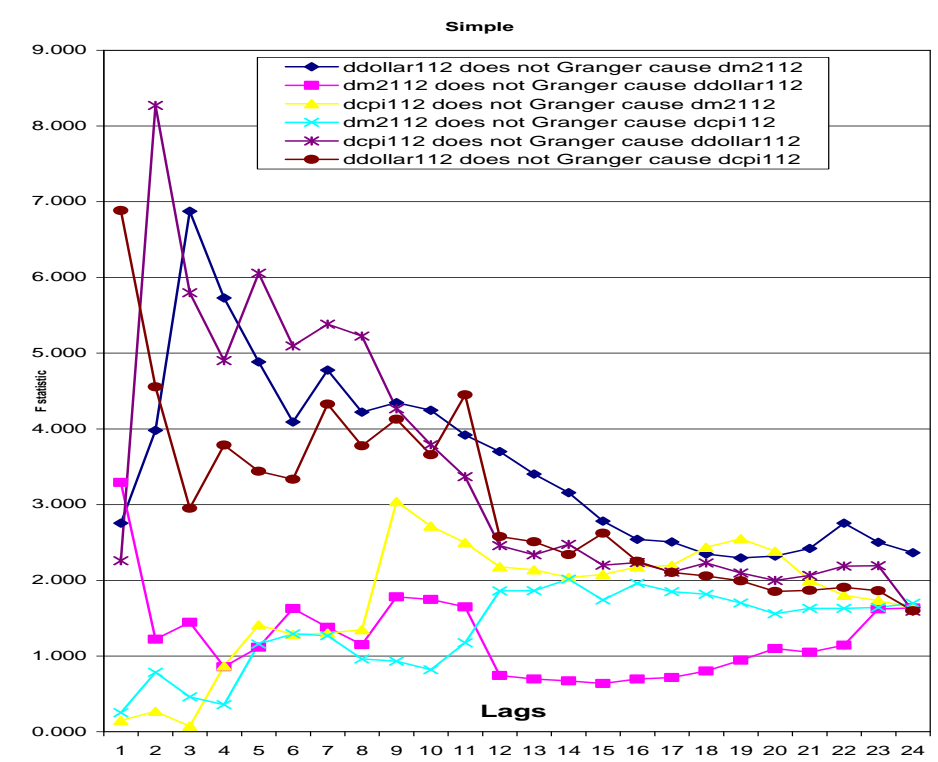

\begin{tabular}{rrrrrrr}
\hline Simple & \multicolumn{7}{c}{ Probability } & dm2112 \\
\hline $\begin{array}{c}\text { Number } \\
\text { of Lags }\end{array}$ & $\begin{array}{c}\text { ddollar11 } \\
\text { 2 does not } \\
\text { Granger } \\
\text { cause } \\
\text { dm2112 }\end{array}$ & $\begin{array}{c}\text { dm2112 } \\
\text { does not } \\
\text { Granger } \\
\text { cause } \\
\text { ddollar112 }\end{array}$ & $\begin{array}{c}\text { dcpi112 } \\
\text { does not } \\
\text { Granger } \\
\text { cause } \\
\text { dm2112 }\end{array}$ & $\begin{array}{c}\text { does not } \\
\text { Granger } \\
\text { cause } \\
\text { dcpi112 }\end{array}$ & $\begin{array}{c}\text { does not } \\
\text { Granger } \\
\text { cause } \\
\text { ddollar112 }\end{array}$ & $\begin{array}{c}\text { ddollar11 } \\
\text { 2 does not } \\
\text { Granger } \\
\text { cause } \\
\text { dcpi112 }\end{array}$ \\
\hline $\mathbf{1}$ & 0.098 & 0.071 & 0.700 & 0.617 & 0.134 & 0.009 \\
\hline $\mathbf{2}$ & 0.020 & 0.297 & 0.764 & 0.457 & 0.000 & 0.011 \\
\hline $\mathbf{3}$ & 0.000 & 0.231 & 0.975 & 0.710 & 0.000 & 0.034 \\
\hline $\mathbf{4}$ & 0.000 & 0.490 & 0.483 & 0.839 & 0.000 & 0.005 \\
\hline $\mathbf{5}$ & 0.000 & 0.353 & 0.223 & 0.332 & 0.000 & 0.005 \\
\hline $\mathbf{6}$ & 0.000 & 0.143 & 0.266 & 0.263 & 0.000 & 0.004 \\
\hline $\mathbf{7}$ & 0.000 & 0.217 & 0.251 & 0.268 & 0.000 & 0.000 \\
\hline $\mathbf{8}$ & 0.000 & 0.333 & 0.222 & 0.467 & 0.000 & 0.000 \\
\hline $\mathbf{9}$ & 0.000 & 0.076 & 0.002 & 0.499 & 0.000 & 0.000 \\
\hline $\mathbf{1 0}$ & 0.000 & 0.075 & 0.004 & 0.611 & 0.000 & 0.000 \\
\hline $\mathbf{1 1}$ & 0.000 & 0.091 & 0.006 & 0.307 & 0.000 & 0.000 \\
\hline $\mathbf{1 2}$ & 0.000 & 0.707 & 0.014 & 0.042 & 0.006 & 0.004 \\
\hline $\mathbf{1 3}$ & 0.000 & 0.766 & 0.014 & 0.037 & 0.007 & 0.004 \\
\hline $\mathbf{1 4}$ & 0.000 & 0.799 & 0.017 & 0.019 & 0.003 & 0.006 \\
\hline $\mathbf{1 5}$ & 0.000 & 0.839 & 0.013 & 0.048 & 0.009 & 0.001 \\
\hline $\mathbf{1 6}$ & 0.001 & 0.793 & 0.007 & 0.018 & 0.006 & 0.006 \\
\hline
\end{tabular}




\begin{tabular}{lllllll}
\hline $\mathbf{1 7}$ & 0.001 & 0.782 & 0.006 & 0.026 & 0.010 & 0.010 \\
\hline $\mathbf{1 8}$ & 0.003 & 0.695 & 0.001 & 0.027 & 0.005 & 0.011 \\
\hline $\mathbf{1 9}$ & 0.003 & 0.531 & 0.000 & 0.041 & 0.008 & 0.013 \\
\hline $\mathbf{2 0}$ & 0.002 & 0.361 & 0.001 & 0.070 & 0.011 & 0.022 \\
\hline $\mathbf{2 1}$ & 0.001 & 0.411 & 0.009 & 0.049 & 0.008 & 0.019 \\
\hline $\mathbf{2 2}$ & 0.000 & 0.314 & 0.021 & 0.047 & 0.004 & 0.015 \\
\hline $\mathbf{2 3}$ & 0.000 & 0.051 & 0.027 & 0.042 & 0.003 & 0.017 \\
\hline $\mathbf{2 4}$ & 0.001 & 0.047 & 0.041 & 0.030 & 0.056 & 0.055 \\
\hline
\end{tabular}

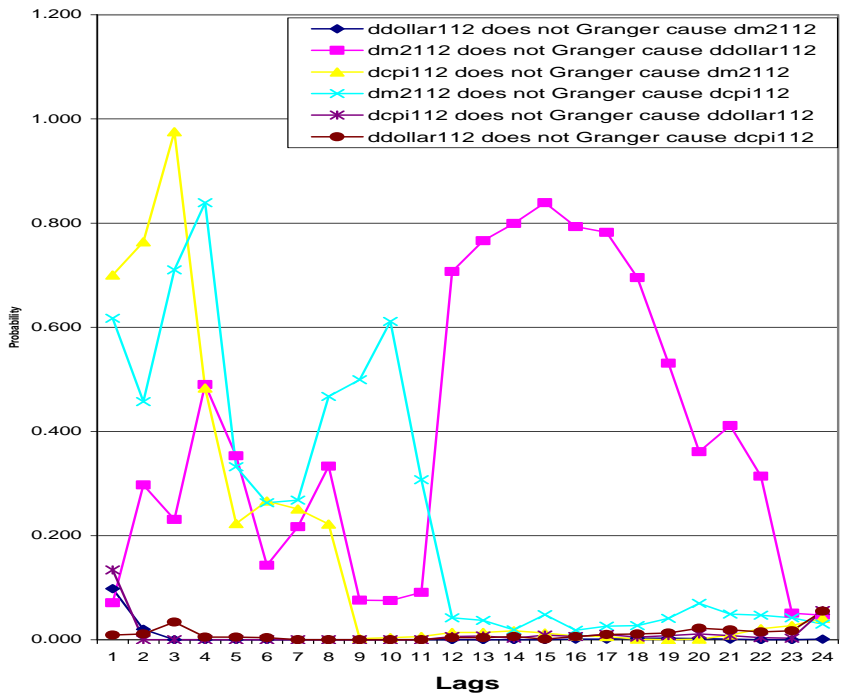

The same study regarding the logarithms of the variables gives the following conclusions:

- Change of Dollar rate affects liquidity after 3 to 5 months.

- Change of liquidity does not affect the Dollar rate.

- Price changes after 3 months affect liquidity.

- Liquidity change does not affect prices.

- Price changes after 6 to 11 months and also after 13 to 15 months causes changes in the Dollar rate.

- Changes in Dollar rate causes changes in prices after 11 months.

In short, the above conclusions can be shown at a $95 \%$ level of significance in the diagram below:
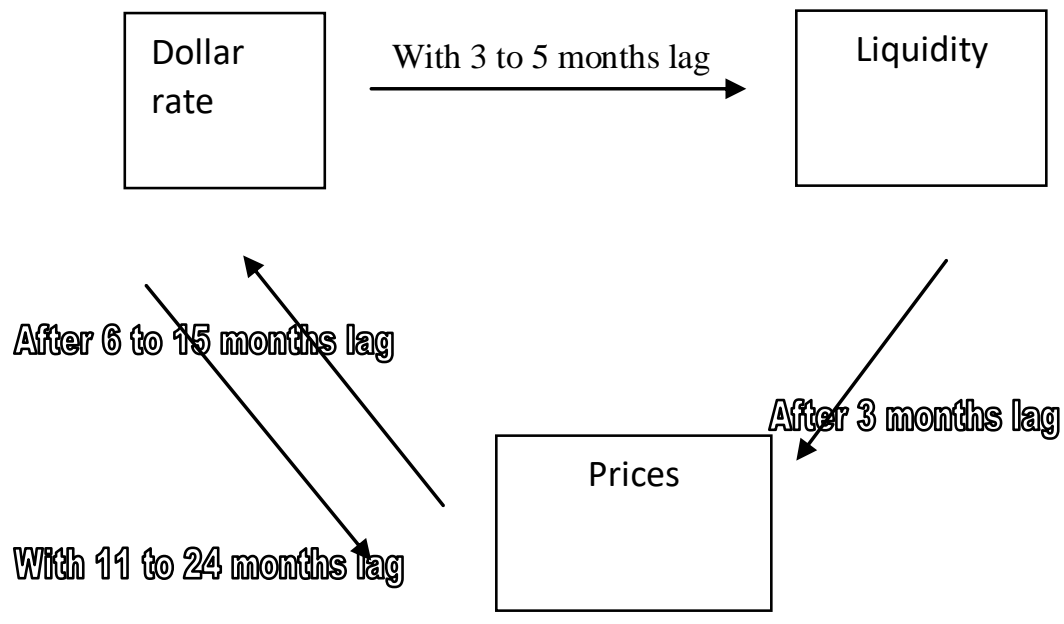


\begin{tabular}{ccccccc}
\hline Log & \multicolumn{5}{c}{ F-Statistics } & \\
\hline $\begin{array}{c}\text { No. } \\
\text { of } \\
\text { Lags }\end{array}$ & $\begin{array}{c}\text { Dlogdollar112 } \\
\text { does not } \\
\text { Granger } \\
\text { cause } \\
\text { dlogm2112 }\end{array}$ & $\begin{array}{c}\text { dlogm2112 } \\
\text { does not } \\
\text { Granger } \\
\text { cause } \\
\text { dlogdollar112 }\end{array}$ & $\begin{array}{c}\text { dlogepi112 } \\
\text { does not } \\
\text { Granger } \\
\text { cause } \\
\text { dlogm2112 }\end{array}$ & $\begin{array}{c}\text { dlogm2112 } \\
\text { does not } \\
\text { Granger } \\
\text { cause } \\
\text { dlogcpi112 }\end{array}$ & $\begin{array}{c}\text { dlogcpi112 } \\
\text { does not } \\
\text { Granger } \\
\text { cause } \\
\text { dlogdollar112 }\end{array}$ & $\begin{array}{c}\text { dlogdollar112 } \\
\text { does not } \\
\text { Granger } \\
\text { cause } \\
\text { dlogcpi112 }\end{array}$ \\
\hline $\mathbf{1}$ & 0.640 & 0.025 & 3.308 & 0.374 & 0.441 & 0.274 \\
\hline $\mathbf{2}$ & 1.910 & 1.789 & 1.586 & 0.226 & 0.273 & 1.323 \\
\hline $\mathbf{3}$ & 4.043 & 1.127 & 2.737 & 0.405 & 1.006 & 1.093 \\
\hline $\mathbf{4}$ & 3.175 & 0.814 & 2.097 & 0.341 & 0.686 & 0.879 \\
\hline $\mathbf{5}$ & 2.397 & 1.061 & 1.734 & 0.923 & 1.811 & 1.007 \\
\hline $\mathbf{6}$ & 1.966 & 0.972 & 1.408 & 0.763 & 2.467 & 1.271 \\
\hline $\mathbf{7}$ & 1.809 & 0.959 & 1.351 & 0.643 & 2.368 & 1.007 \\
\hline $\mathbf{8}$ & 1.614 & 0.945 & 1.166 & 0.527 & 2.274 & 0.920 \\
\hline $\mathbf{9}$ & 1.752 & 0.921 & 1.552 & 0.570 & 2.102 & 0.836 \\
\hline $\mathbf{1 0}$ & 1.544 & 1.029 & 1.393 & 0.629 & 2.449 & 0.881 \\
\hline $\mathbf{1 1}$ & 1.425 & 1.661 & 1.263 & 0.917 & 2.120 & 2.077 \\
\hline $\mathbf{1 2}$ & 0.875 & 0.874 & 0.826 & 0.413 & 1.455 & 1.519 \\
\hline $\mathbf{1 3}$ & 0.742 & 0.796 & 0.851 & 0.385 & 1.920 & 2.059 \\
\hline $\mathbf{1 4}$ & 0.660 & 0.722 & 0.697 & 0.483 & 1.823 & 1.819 \\
\hline $\mathbf{1 5}$ & 0.644 & 0.731 & 0.721 & 0.475 & 2.180 & 2.779 \\
\hline $\mathbf{1 6}$ & 0.593 & 0.823 & 0.780 & 0.540 & 1.555 & 2.759 \\
\hline $\mathbf{1 7}$ & 0.698 & 0.773 & 0.855 & 0.480 & 1.475 & 2.558 \\
\hline $\mathbf{1 8}$ & 0.720 & 0.769 & 0.910 & 0.560 & 1.580 & 2.193 \\
\hline $\mathbf{1 9}$ & 0.693 & 0.854 & 0.854 & 0.559 & 1.521 & 2.185 \\
\hline $\mathbf{2 0}$ & 0.687 & 0.816 & 0.834 & 0.559 & 1.383 & 2.114 \\
\hline $\mathbf{2 1}$ & 0.712 & 0.777 & 0.805 & 0.584 & 1.323 & 2.126 \\
\hline $\mathbf{2 2}$ & 0.701 & 0.761 & 0.814 & 0.602 & 1.323 & 2.379 \\
\hline $\mathbf{2 3}$ & 0.595 & 0.752 & 0.914 & 0.541 & 1.509 & 2.569 \\
\hline $\mathbf{2 4}$ & 0.599 & 0.840 & 0.796 & 0.561 & 0.965 & 2.398 \\
\hline & & & & & & \\
\hline
\end{tabular}

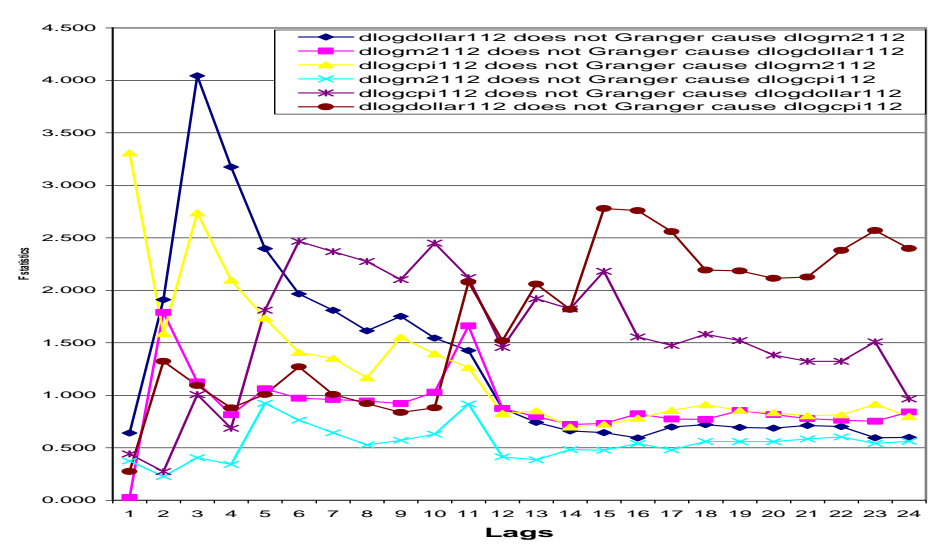




\begin{tabular}{|c|c|c|c|c|c|c|}
\hline \multirow{2}{*}{$\begin{array}{c}\text { Log } \\
\text { No. } \\
\text { of } \\
\text { Lags }\end{array}$} & \multicolumn{6}{|c|}{ Probability } \\
\hline & $\begin{array}{c}\text { dlogdollar112 } \\
\text { does not } \\
\text { Granger } \\
\text { cause } \\
\text { dlogm2112 }\end{array}$ & $\begin{array}{c}\text { dlogm2112 } \\
\text { does not } \\
\text { Granger } \\
\text { cause } \\
\text { dlogdollar112 }\end{array}$ & $\begin{array}{c}\text { dlogepi112 } \\
\text { does not } \\
\text { Granger } \\
\text { cause } \\
\text { dlogm2112 }\end{array}$ & $\begin{array}{c}\text { dlogm2112 } \\
\text { does not } \\
\text { Granger } \\
\text { cause } \\
\text { dlogcpi112 }\end{array}$ & $\begin{array}{c}\text { dlogcpi112 } \\
\text { does not } \\
\text { Granger } \\
\text { cause } \\
\text { dlogdollar112 }\end{array}$ & $\begin{array}{c}\text { dlogdollar112 } \\
\text { does not } \\
\text { Granger } \\
\text { cause } \\
\text { dlogcpi112 }\end{array}$ \\
\hline 1 & 0.424 & 0.872 & 0.070 & 0.541 & 0.507 & 0.600 \\
\hline 2 & 0.151 & 0.170 & 0.207 & 0.797 & 0.761 & 0.268 \\
\hline 3 & 0.008 & 0.339 & 0.044 & 0.749 & 0.391 & 0.353 \\
\hline 4 & 0.015 & 0.517 & 0.082 & 0.849 & 0.602 & 0.477 \\
\hline 5 & 0.039 & 0.383 & 0.128 & 0.467 & 0.113 & 0.415 \\
\hline 6 & 0.073 & 0.445 & 0.213 & 0.599 & 0.026 & 0.273 \\
\hline 7 & 0.088 & 0.462 & 0.228 & 0.719 & 0.025 & 0.427 \\
\hline 8 & 0.124 & 0.480 & 0.321 & 0.834 & 0.025 & 0.501 \\
\hline 9 & 0.081 & 0.507 & 0.133 & 0.819 & 0.032 & 0.583 \\
\hline 10 & 0.129 & 0.421 & 0.186 & 0.787 & 0.009 & 0.552 \\
\hline 11 & 0.167 & 0.087 & 0.249 & 0.525 & 0.022 & 0.025 \\
\hline 12 & 0.573 & 0.573 & 0.623 & 0.956 & 0.147 & 0.123 \\
\hline 13 & 0.718 & 0.663 & 0.604 & 0.973 & 0.032 & 0.020 \\
\hline 14 & 0.808 & 0.748 & 0.774 & 0.939 & 0.040 & 0.041 \\
\hline 15 & 0.833 & 0.748 & 0.759 & 0.950 & 0.009 & 0.000 \\
\hline 16 & 0.884 & 0.656 & 0.705 & 0.921 & 0.090 & 0.000 \\
\hline 17 & 0.799 & 0.720 & 0.627 & 0.958 & 0.113 & 0.001 \\
\hline 18 & 0.784 & 0.732 & 0.566 & 0.922 & 0.075 & 0.006 \\
\hline 19 & 0.819 & 0.638 & 0.638 & 0.929 & 0.089 & 0.005 \\
\hline 20 & 0.831 & 0.689 & 0.669 & 0.934 & 0.143 & 0.007 \\
\hline 21 & 0.812 & 0.740 & 0.709 & 0.923 & 0.174 & 0.006 \\
\hline 22 & 0.829 & 0.764 & 0.703 & 0.917 & 0.172 & 0.001 \\
\hline 23 & 0.923 & 0.781 & 0.579 & 0.956 & 0.082 & 0.000 \\
\hline 24 & 0.925 & 0.678 & 0.736 & 0.949 & 0.516 & 0.001 \\
\hline
\end{tabular}

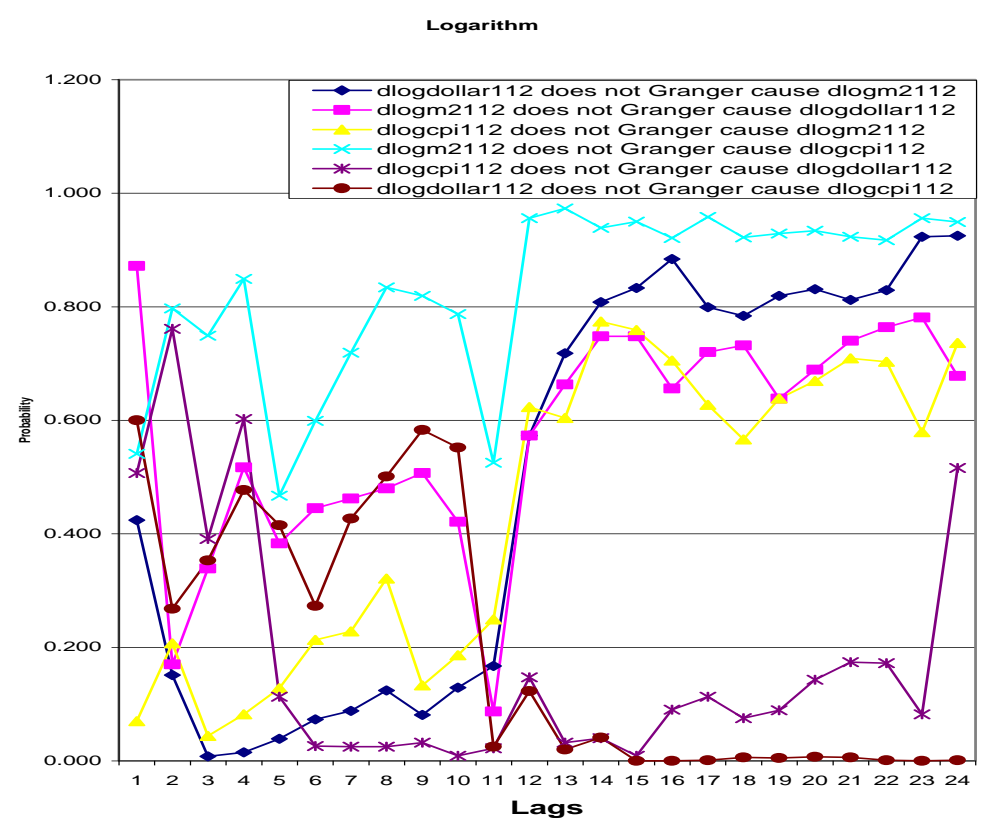


Adding up the above results, we can draw the following diagram for short term analysis:

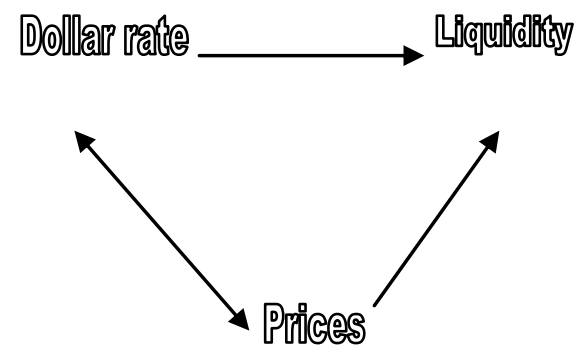

The following diagram is for more than a year analysis:

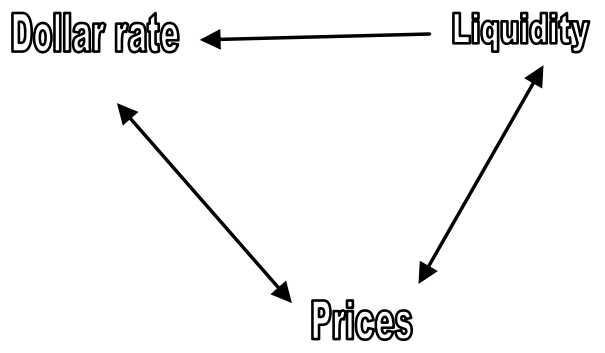

The above diagrams show that foreign exchange rate cannot be regulated by changing liquidity in less than a month, and the results show that only the general price level can affect this variable. But in one to two years of analysis, the foreign exchange rate can be regulated by liquidity control. In other words, the long run trend of the foreign exchange rate is affected by liquidity and price level changes, but since price changes have also short term effects on the foreign exchange rate, therefore, we can change this hypothesis in error correction model as follows:

Foreign exchange rate $=$ long term function (price level, liquidity) + error

If in the first order stationary condition of the three variables of the foreign exchange rate, liquidity, and price level, the co-integrated regression creates stationary error, we follow the error correction model.

After the study of the foreign exchange rate, liquidity, and price index variables and making them stationary, we follow the model with stationary variables. With the estimation of long-run function, we realized that the existing co-linearity between liquidity and CPI, practically the obtained weights are not as they were expected and therefore, it is not possible to follow error correction model.

On the basis of obtained graphs and results for long run effects, we consider the three following relationships:

EQ1: DOLLAR $=\mathrm{C}(1) * \mathrm{M} 2+\mathrm{C}(2) * \mathrm{DUMMY} 8000+\mathrm{C}(3) * \mathrm{DUMMY} 8000 * \mathrm{M} 2+\mathrm{C}(4)+$ reseq1

$\mathrm{EQ} 2: \mathrm{M} 2=\mathrm{C}(11) * \mathrm{CPI}+\mathrm{C}(12)+\mathrm{C}(13) * \mathrm{DUMMY} 8000+\mathrm{C}(14) * \mathrm{DUMMY} 8000 * \mathrm{CPI}+$ reseq2

$\mathrm{EQ} 3: \mathrm{CPI}=(\mathrm{C}(21)+\mathrm{C}(22) * \mathrm{DUMMY} 8000) * \mathrm{DOLLAR}+(\mathrm{C}(23)+\mathrm{C}(24) * \mathrm{DUMMY} 8000) * \mathrm{M} 2$

$+\mathrm{C}(25)+\mathrm{C}(26) * \mathrm{DUMMY} 8000+$ reseq3

These equations show the mathematical causality relationship between our variables. Regarding the existence of high co-linearity between liquidity and price level, the price variable has been omitted from the first equation. In order to consider the policies for fixing Dollar rate at 8000 Rials, the dummy variable "dummy8000" has been introduced into the model which affects the intercept, as well as the slope. The amount of this dummy from the $11^{\text {th }}$ 
month of 1998 and afterward is one, and for other times is zero. The long term regression results regarding the structural changes in foreign exchange rates and graphs are presented on the next pages.

\begin{tabular}{|c|c|c|c|c|}
\hline \multicolumn{5}{|c|}{ Dependent Variable: DOLLAR } \\
\hline \multicolumn{5}{|c|}{ Method: Least Squares } \\
\hline \multicolumn{5}{|c|}{ Sample(adjusted): 1365:01 1380:12 } \\
\hline \multicolumn{5}{|c|}{ Included observations: 192 after adjusting endpoints } \\
\hline \multicolumn{5}{|c|}{ DOLLAR $=\mathrm{C}(1) * \mathrm{M} 2+\mathrm{C}(2) *$ DUMMY8000+C(3)*DUMMY8000*M2+C(4) } \\
\hline & Coefficient & Std. Error & t-Statistic & Prob. \\
\hline $\mathrm{C}(1)$ & 0.039448 & 0.000673 & 58.65213 & 0.0000 \\
\hline $\mathrm{C}(2)$ & 8738.370 & 269.5357 & 32.42008 & 0.0000 \\
\hline $\mathrm{C}(3)$ & -0.043906 & 0.001354 & -32.42936 & 0.0000 \\
\hline $\mathrm{C}(4)$ & 511.6349 & 43.06389 & 11.88083 & 0.0000 \\
\hline R-squared & 0.984707 & \multicolumn{2}{|c|}{ Mean dependent var } & 3590.353 \\
\hline Adjusted R-squared & 0.984463 & \multicolumn{2}{|c|}{ S.D. dependent var } & 2774.293 \\
\hline S.E. of regression & 345.8132 & \multicolumn{2}{|c|}{ Akaike info criterion } & 14.55029 \\
\hline Sum squared resid & 22482313 & \multicolumn{2}{|c|}{ Schwarz criterion } & 14.61815 \\
\hline Log-likelihood & -1392.828 & \multicolumn{2}{|c|}{ Durbin-Watson stat } & 0.358974 \\
\hline
\end{tabular}

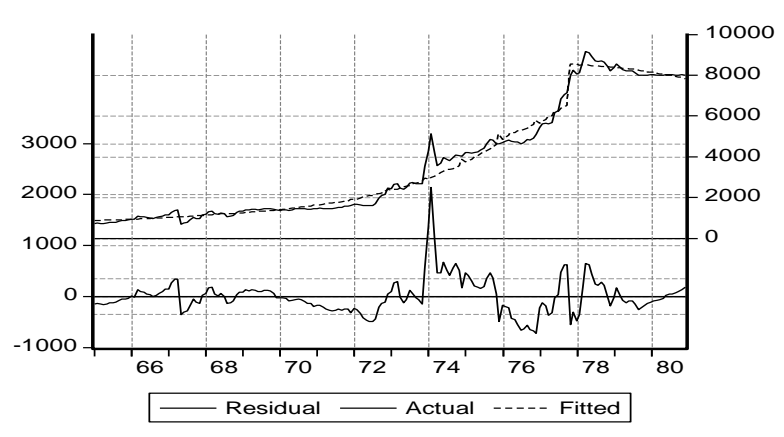

\begin{tabular}{|c|c|c|c|c|}
\hline \multicolumn{5}{|c|}{ Dependent Variable: M2 } \\
\hline \multicolumn{5}{|c|}{ Method: Least Squares } \\
\hline \multicolumn{5}{|c|}{ Sample(adjusted): 1365:01 1380:12 } \\
\hline \multicolumn{5}{|c|}{ Included observations: 192 after adjusting endpoints } \\
\hline \multicolumn{5}{|c|}{$\mathrm{M} 2=\mathrm{C}(11) * \mathrm{CPI}+\mathrm{C}(12)+\mathrm{C}(13) * \mathrm{DUMMY} 8000+\mathrm{C}(14) * \mathrm{DUMMY} 8000 * \mathrm{CPI}$} \\
\hline & Coefficien & Std. Error & t-Statistic & Prob. \\
\hline \multicolumn{5}{|c|}{$\mathrm{t}$} \\
\hline $\mathrm{C}(11)$ & 1194.194 & 14.32809 & 83.34637 & 0.0000 \\
\hline $\mathrm{C}(12)$ & -2595.321 & 790.6147 & -3.282662 & 0.0012 \\
\hline $\mathrm{C}(13)$ & -212425.6 & 9423.653 & -22.54175 & 0.0000 \\
\hline $\mathrm{C}(14)$ & 1565.863 & 60.77294 & 25.76579 & 0.0000 \\
\hline R-squared & 0.994373 & \multicolumn{2}{|c|}{ Mean dependent var } & 82963.88 \\
\hline Adjusted R-squared & 0.994283 & \multicolumn{2}{|c|}{ S.D. dependent var } & 81166.19 \\
\hline S.E. of regression & 6137.162 & \multicolumn{2}{|c|}{ Akaike info criterion } & 20.30273 \\
\hline Sum squared resid & $7.08 \mathrm{E}+09$ & \multicolumn{2}{|c|}{ Schwarz criterion } & 20.37059 \\
\hline Log-likelihood & -1945.062 & \multicolumn{2}{|c|}{ Durbin-Watson stat } & 0.295806 \\
\hline
\end{tabular}




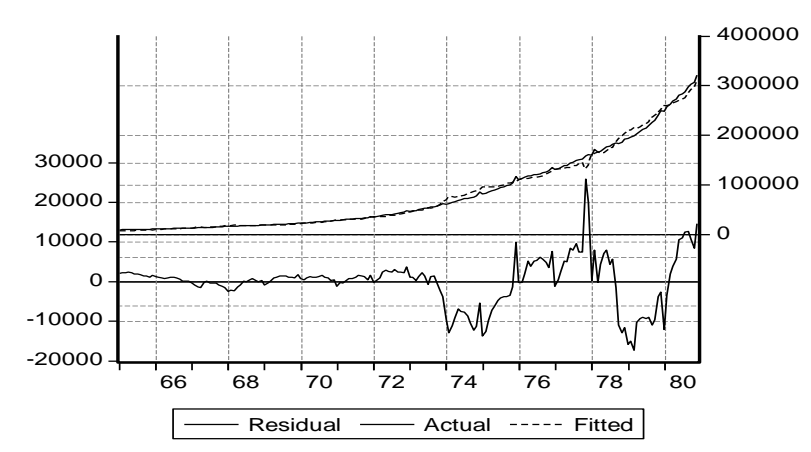

\begin{tabular}{|c|c|c|c|c|}
\hline \multicolumn{5}{|c|}{ Dependent Variable: CPI } \\
\hline \multicolumn{5}{|c|}{ Method: Least Squares } \\
\hline \multicolumn{5}{|c|}{ Sample(adjusted): 1365:01 1380:12 } \\
\hline \multicolumn{5}{|c|}{ Included observations: 192 after adjusting endpoints } \\
\hline \multicolumn{5}{|c|}{$\mathrm{CPI}=(\mathrm{C}(21)+\mathrm{C}(22) * \mathrm{DUMMY} 8000) *$ DOLLAR $+(\mathrm{C}(23)+\mathrm{C}(24)$} \\
\hline \multicolumn{5}{|c|}{ *DUMMY 8000$) * \mathrm{M} 2+\mathrm{C}(25)+\mathrm{C}(26) *$ DUMMY 8000} \\
\hline \multirow{2}{*}{\multicolumn{5}{|c|}{$\mathrm{t}$}} \\
\hline & & & & \\
\hline $\mathrm{C}(21)$ & 0.006521 & 0.000650 & 10.02795 & 0.0000 \\
\hline $\mathrm{C}(22)$ & -0.007401 & 0.001988 & -3.722975 & 0.0003 \\
\hline $\mathrm{C}(23)$ & 0.000572 & $2.63 \mathrm{E}-05$ & 21.75495 & 0.0000 \\
\hline $\mathrm{C}(24)$ & -0.000231 & $2.93 \mathrm{E}-05$ & -7.896540 & 0.0000 \\
\hline $\mathrm{C}(25)$ & -0.741588 & 0.492289 & -1.506408 & 0.1337 \\
\hline $\mathrm{C}(26)$ & 90.81921 & 17.52777 & 5.181447 & 0.0000 \\
\hline R-squared & 0.997358 & \multicolumn{2}{|c|}{ Mean dependent var } & 65.82188 \\
\hline Adjusted R-squared & 0.997287 & \multicolumn{2}{|c|}{ S.D. dependent var } & 55.94090 \\
\hline S.E. of regression & 2.913712 & \multicolumn{2}{|c|}{ Akaike info criterion } & 5.007484 \\
\hline Sum squared resid & 1579.087 & \multicolumn{2}{|c|}{ Schwarz criterion } & 5.109281 \\
\hline Log-likelihood & -474.7185 & \multicolumn{2}{|c|}{ Durbin-Watson stat } & 0.290870 \\
\hline
\end{tabular}
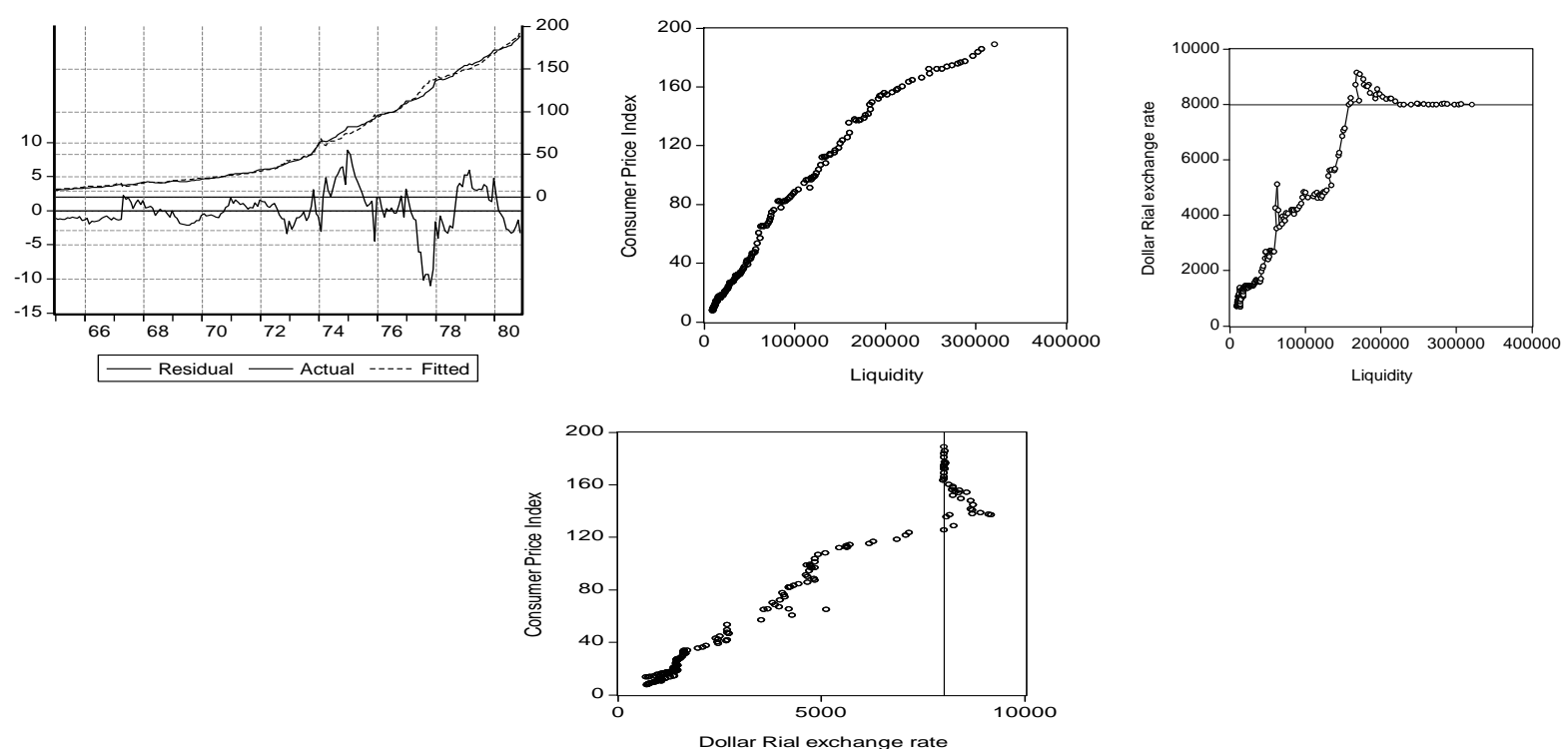


\section{Further study of co-integration}

In order to study the co-integration and concluding whether the mentioned relationships are long term relationships or not, we regress the first order difference of the residuals of each regression to its own lag. In this way, we conduct the unit root test. This study is shown in the next graphs. The results of these tests with the study of MacKinnon show that all three equations have long term nature. In other words:

- Liquidity affects the foreign exchange rate in the long run.

- Prices affect liquidity in the long run.

- In the long run, both liquidity and Dollar rate affect prices.

\begin{tabular}{|c|c|c|c|c|}
\hline \\
\hline \multicolumn{5}{|c|}{ Method: Least Squares } \\
\hline \multicolumn{5}{|c|}{ Sample(adjusted): 1365:02 1380:12 } \\
\hline \multicolumn{5}{|c|}{ Included observations: 191 after adjusting endpoints } \\
\hline Variable & $\begin{array}{r}\text { Coefficien } \\
\mathrm{t}\end{array}$ & Std. Error & t-Statistic & Prob. \\
\hline RESEQ1(-1) & -0.179557 & 0.041502 & -4.326501 & 0.0000 \\
\hline R-squared & 0.089617 & Mean dep & lent var & 1.756606 \\
\hline Adjusted R-squared & 0.089617 & S.D. depe & nt var & 206.0912 \\
\hline S.E. of regression & 196.6398 & Akaike in & riterion & 13.40585 \\
\hline Sum squared resid & 7346772. & Schwarz c & rion & 13.42287 \\
\hline Log-likelihood & -1279.258 & Durbin-W & on stat & 1.546716 \\
\hline
\end{tabular}

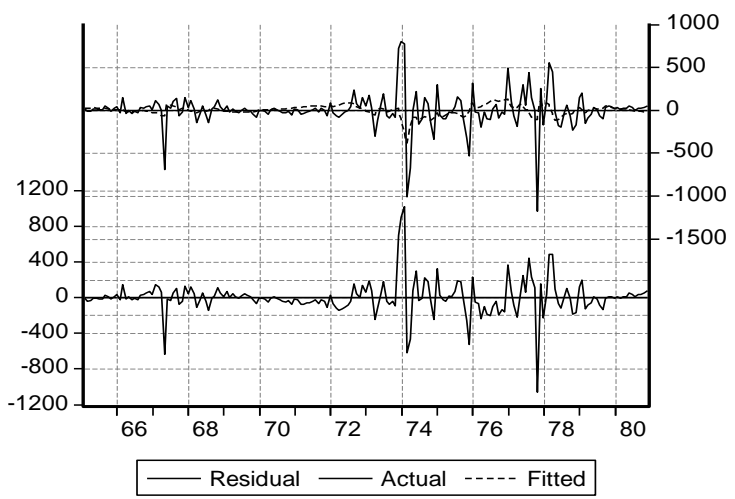

\begin{tabular}{|c|c|c|c|c|}
\hline \multicolumn{5}{|c|}{ Dependent Variable: D(RESEQ2) } \\
\hline \multicolumn{5}{|c|}{ Method: Least Squares } \\
\hline \multicolumn{5}{|c|}{ Sample(adjusted): 1365:02 1380:12 } \\
\hline \multicolumn{5}{|c|}{ Included observations: 191 after adjusting endpoints } \\
\hline Variable & $\begin{array}{r}\text { Coefficien } \\
\mathrm{t}\end{array}$ & Std. Error & t-Statistic & Prob. \\
\hline RESEQ2(-1) & -0.137304 & 0.038807 & -3.538106 & 0.0005 \\
\hline R-squared & 0.061448 & \multicolumn{2}{|c|}{ Mean dependent var } & 65.24131 \\
\hline Adjusted R-squared & 0.061448 & \multicolumn{2}{|c|}{ S.D. dependent var } & 3319.627 \\
\hline S.E. of regression & 3216.017 & \multicolumn{2}{|c|}{ Akaike info criterion } & 18.99490 \\
\hline Sum squared resid & $1.97 \mathrm{E}+09$ & \multicolumn{2}{|c|}{ Schwarz criterion } & 19.01192 \\
\hline Log-likelihood & -1813.013 & \multicolumn{2}{|c|}{ Durbin-Watson stat } & 2.149772 \\
\hline
\end{tabular}




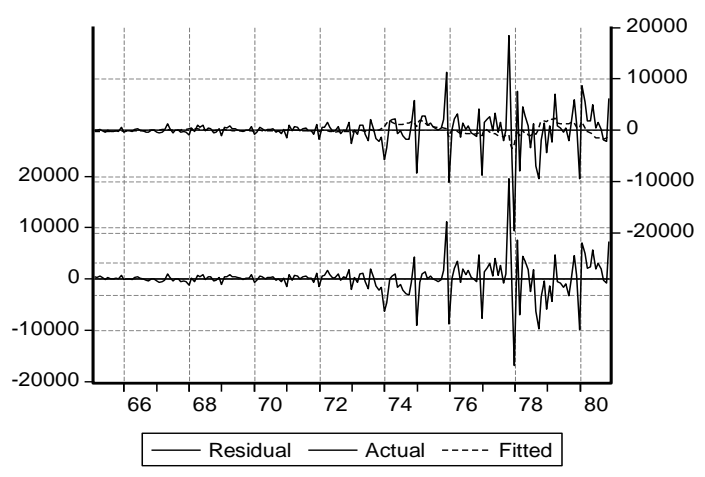

\begin{tabular}{|c|c|c|c|c|}
\hline \multicolumn{5}{|c|}{ Dependent Variable: D(RESEQ3) } \\
\hline \multicolumn{5}{|c|}{ Method: Least Squares } \\
\hline \multicolumn{5}{|c|}{ Sample(adjusted): 1365:02 1380:12 } \\
\hline \multicolumn{5}{|c|}{ Included observations: 191 after adjusting endpoints } \\
\hline Variable & Coefficien & Std. Error & t-Statistic & Prob. \\
\hline RESEQ3(-1) & -0.143351 & 0.037861 & -3.786216 & 0.0002 \\
\hline R-squared & 0.070105 & Mean dep & lent var & 0.011469 \\
\hline Adjusted R-squared & 0.070105 & S.D. depe & nt var & 1.554762 \\
\hline S.E. of regression & 1.499273 & Akaike in & riterion & 3.653060 \\
\hline Sum squared resid & 427.0858 & Schwarz c & erion & 3.670087 \\
\hline Log-likelihood & -347.8672 & Durbin-W & on stat & 2.238935 \\
\hline
\end{tabular}

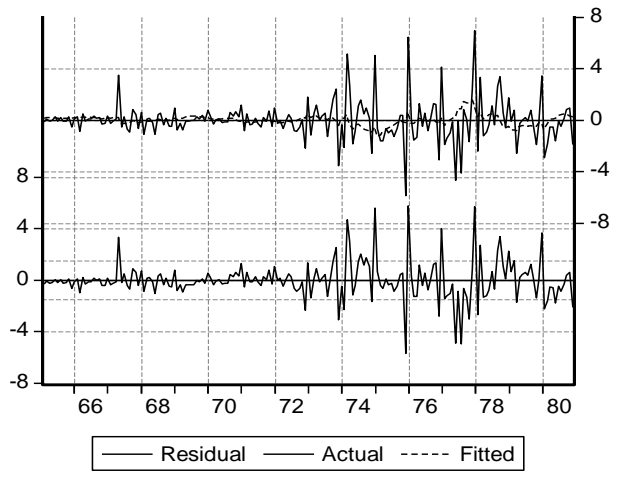

\section{Selling foreign exchange}

One of the variables which have not been used here is the selling of foreign exchange in the parallel market. As it was mentioned, the application of this policy can affect the monetary and exchange sectors of the economy. Unfortunately, the monthly data for this variable is not available; the annual data as budget information is available in the central bank reports. These figures have been presented in the previous sections of this paper. Studies show the relationship between this variable and the foreign exchange rate in the parallel market. The Macro-econometric model of Iran ${ }^{11}$ shows that there is a significant relationship between selling foreign exchange in the parallel market and Dollar rate in that market. The following relationship has been defined in that model:

Dollar rate $=\mathrm{f}($ selling exchange in parallel market, liquidity, cumulative balance of payments)

The above study showed that it is not possible to find a significant relationship for the above function in the short

11 - Bidabad, 1996. http://www.bidabad.com/ 
run, even though this function is statistically satisfactory. The reason for that is perhaps the lack of monthly data series of selling foreign exchange for a long period. As it was mentioned, there is a long term relationship between these variables; a concrete short-run relationship has not been found. The cross-correlogram below shows: selling foreign exchange with different lags has little effects with different directions on the parity rate of Rial. The next graph shows the same conclusion for the relationship between liquidity and Dollar rate. In other words, in spite of the existence of a relationship, in the long run, it is not possible to define such a relationship in the short run. The same is understood for the position of balance of payments and the foreign exchange rate in the short run, which is shown in the next table.

\begin{tabular}{|c|c|c|c|}
\hline \multicolumn{4}{|l|}{ Sample: 1365:01 1381:12 } \\
\hline Included observations: 67 & & & \\
\hline \multicolumn{4}{|l|}{ Correlations are asymptotically consistent approximations } \\
\hline $\begin{array}{cc}\text { D(DOLLAR),D(DOLLARSAL } & \text { D(DOLLAR),D(DOLLARSAL } \\
\text { E)(-i) } & \text { E)(+i) }\end{array}$ & $\mathrm{i}$ & lag & lead \\
\hline \begin{tabular}{ll|l|l|}
$*$ & $\mid$ &.$*$ & $\mid$
\end{tabular} & 0 & $\begin{array}{r}-140 \\
0.14\end{array}$ & 0.140 \\
\hline. $\mid$ & 1 & $\begin{array}{r}- \\
0.026 \\
9\end{array}$ & $\begin{array}{r}- \\
0.038 \\
1\end{array}$ \\
\hline.$\left.\right|^{*}$ & 2 & $\begin{array}{r}0.074 \\
5\end{array}$ & $\begin{array}{r}- \\
0.011 \\
0\end{array}$ \\
\hline.$\left.\right|^{*}$ & 3 & $\begin{array}{r}- \\
0.010 \\
9\end{array}$ & $\begin{array}{r}0.107 \\
9\end{array}$ \\
\hline.$*$ & 4 & $\begin{array}{r}- \\
0.045 \\
4\end{array}$ & $\begin{array}{r}- \\
0.101 \\
7\end{array}$ \\
\hline.$*$ & 5 & $\begin{array}{r}- \\
0.136 \\
5 \\
\end{array}$ & $\begin{array}{r}- \\
0.067 \\
5 \\
\end{array}$ \\
\hline.$\left.\right|^{*}$ & 6 & $\begin{array}{r}0.047 \\
5\end{array}$ & $\begin{array}{r}0.064 \\
1\end{array}$ \\
\hline.$*$ & 7 & $\begin{array}{r}- \\
0.105 \\
3 \\
\end{array}$ & $\begin{array}{r}- \\
0.063 \\
2 \\
\end{array}$ \\
\hline.$\left.\right|^{*}$. & 8 & $\begin{array}{r}0.108 \\
4 \\
\end{array}$ & $\begin{array}{r}0.019 \\
0 \\
\end{array}$ \\
\hline.$*$ & 9 & $\begin{array}{r}0.028 \\
0\end{array}$ & $\begin{array}{r}- \\
0.108 \\
1 \\
\end{array}$ \\
\hline$* * *$. & $\begin{array}{l}1 \\
0\end{array}$ & $\begin{array}{r}- \\
0.204 \\
8 \\
\end{array}$ & $\begin{array}{r}- \\
0.078 \\
9 \\
\end{array}$ \\
\hline.$\left.\right|^{*}$ & $\begin{array}{l}1 \\
1\end{array}$ & $\begin{array}{r}0.114 \\
2\end{array}$ & $\begin{array}{r}-027 \\
0.02\end{array}$ \\
\hline$\left.\cdot\right|^{* *}$ & $\begin{array}{l}1 \\
2\end{array}$ & $\begin{array}{r}0.160 \\
5 \\
\end{array}$ & $\begin{array}{r}0.050 \\
1\end{array}$ \\
\hline. $\mid$. & $\begin{array}{l}1 \\
3\end{array}$ & $\begin{array}{r}0.000 \\
5 \\
\end{array}$ & $\begin{array}{r}0.031 \\
6 \\
\end{array}$ \\
\hline$. * 1 . \quad \mid$ & $\begin{array}{l}1 \\
4\end{array}$ & 0.065 & $0.165^{-}$ \\
\hline
\end{tabular}




\begin{tabular}{|c|c|c|c|c|}
\hline & & & 5 & $\overline{0}$ \\
\hline .1 . & .1. & 1 & 0.021 & - \\
\hline & & 5 & 8 & 0.000 \\
\hline \multirow{3}{*}{$\left.\right|^{*}$. } & $* 1$ & 1 & 0126 & 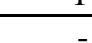 \\
\hline &. & $\begin{array}{l}1 \\
6\end{array}$ & $\begin{array}{r}0.120 \\
6\end{array}$ & 0.047 \\
\hline & & & & 6 \\
\hline \multirow[t]{2}{*}{$\left.\right|^{*}}$. & .*1. & 1 & 0.055 & - \\
\hline & & 7 & 0 & 0.068 \\
\hline \multirow{2}{*}{.1.} & $1 *$ & 1 & 0008 & 0074 \\
\hline & & 8 & 6 & 7 \\
\hline \multirow{3}{*}{.1.} & $* * \mid$. & 1 & - & - \\
\hline & & 9 & 0.028 & 0.189 \\
\hline & & & 8 & 2 \\
\hline \multirow{3}{*}{.1.} & .*1. & 2 & - & - \\
\hline & & 0 & 0.000 & 0.074 \\
\hline & & & 4 & 6 \\
\hline \multirow{2}{*}{.1.} & .*1. & 2 & 0.032 & - \\
\hline & & 1 & 4 & 0.095 \\
\hline \multirow{2}{*}{$\left.\right|^{*}}$. & $1 *$ & & & $\frac{1}{0000}$ \\
\hline & & 2 & $\begin{array}{r}0.067 \\
8\end{array}$ & 0.099 \\
\hline \multirow[t]{2}{*}{.1 . } &.$\left.\right|^{*}$. & 2 & 0.038 & 0.050 \\
\hline & & 3 & 7 & 0 \\
\hline \multirow[t]{3}{*}{$. * \mid$. } & $* * \mid$. & 2 & - & - \\
\hline & & 4 & 0.044 & 0.192 \\
\hline & & & 0 & 8 \\
\hline \multirow[t]{3}{*}{.1.} & .*1. & 2 & 0.002 & - \\
\hline & & 5 & 5 & 0.129 \\
\hline & & & & 9 \\
\hline \multirow[t]{2}{*}{$\left.\right|^{*}}$. & .1. & 2 & 0.090 & - \\
\hline & & 6 & 9 & 0.006 \\
\hline \multirow{2}{*}{.1.} & $1 *$ & 2 & 0008 & $\frac{9}{0.123}$ \\
\hline & $.1 \%$ & 7 & $\begin{array}{r}r .000 \\
6\end{array}$ & $\begin{array}{r}0.125 \\
6\end{array}$ \\
\hline \multirow[t]{2}{*}{.1.} & $* * \mid$. & 2 & 0.011 & - \\
\hline & & 8 & 2 & 0.153 \\
\hline
\end{tabular}

\begin{tabular}{|c|c|c|c|c|}
\hline \multicolumn{5}{|l|}{ Sample: 1365:01 1381:12 } \\
\hline \multicolumn{5}{|c|}{ Included observations: 203} \\
\hline \multicolumn{5}{|c|}{ Correlations are asymptotically consistent approximations } \\
\hline D(DOLLAR),D(M2)(-i) & $\mathrm{D}(\mathrm{DOLLAR}), \mathrm{D}(\mathrm{M} 2)(+\mathrm{i})$ & $\mathrm{i}$ & lag & lead \\
\hline *. $\mid$ & $*|. \quad|$ & 0 & $\begin{array}{r}- \\
0.063 \\
7\end{array}$ & $\begin{array}{r}- \\
0.063 \\
7\end{array}$ \\
\hline | & $* \mid$. & 1 & $\begin{array}{r}- \\
0.003 \\
2\end{array}$ & $\begin{array}{r}- \\
0.104 \\
6\end{array}$ \\
\hline.$\left.\right|^{*}$ &. & 2 & $\begin{array}{r}0.073 \\
5 \\
\end{array}$ & $\begin{array}{r}0.029 \\
0 \\
\end{array}$ \\
\hline .1. & $.1^{*}$ & 3 & 0.001 & 0.094 \\
\hline
\end{tabular}




\begin{tabular}{|c|c|c|c|c|}
\hline & & & 8 & 5 \\
\hline \multirow[t]{3}{*}{$*}$. & $* \mid$. & 4 & - & - \\
\hline & & & 0.042 & 0.079 \\
\hline & & & 7 & 5 \\
\hline \multirow[t]{3}{*}{.1.} & .1. & 5 & - & - \\
\hline & & & 0.039 & 0.022 \\
\hline & & & 4 & 8 \\
\hline \multirow{3}{*}{.1.} & .1. & 6 & - & 0.021 \\
\hline & & & 0.011 & 5 \\
\hline & & & 6 & \\
\hline \multirow{3}{*}{$* 1}$. & $* \mid$. & 7 & - & - \\
\hline & & & 0.047 & 0.097 \\
\hline & & & 8 & 2 \\
\hline \multirow{3}{*}{.1.} & $* \mid$. & 8 & 0.016 & - \\
\hline & & & 5 & 0.056 \\
\hline & & & & 5 \\
\hline \multirow{3}{*}{.1.} & .1. & 9 & 0.020 & - \\
\hline & & & 2 & 0.026 \\
\hline & & & & 5 \\
\hline \multirow{3}{*}{$* \mid$} &.$^{*}$ & 1 & - & 0.060 \\
\hline & & 0 & 0.066 & 6 \\
\hline & & & 8 & \\
\hline \multirow{3}{*}{$* \mid$} & $* \mid$. & 1 & - & - \\
\hline & & 1 & 0.054 & 0.060 \\
\hline & & & 7 & 8 \\
\hline \multirow{3}{*}{.1.} & .1. & 1 & 0.015 & - \\
\hline & & 2 & 4 & 0.040 \\
\hline & & & & 8 \\
\hline \multirow{3}{*}{.1.} & $* \mid$. & 1 & - & - \\
\hline & & 3 & 0.024 & 0.043 \\
\hline & & & 6 & 2 \\
\hline \multirow{3}{*}{.} & .1. & 1 & 0.037 & - \\
\hline & & 4 & 1 & 0.009 \\
\hline & & & & 6 \\
\hline \multirow{3}{*}{.1} & .1. & 1 & - & - \\
\hline & & 5 & 0.016 & 0.030 \\
\hline & & & 7 & 3 \\
\hline \multirow{3}{*}{.1.} & $* \mid$. & 1 & - & - \\
\hline & & 6 & 0.028 & 0.056 \\
\hline & & & 4 & 8 \\
\hline \multirow{3}{*}{.1.} & .1. & 1 & - & 0.008 \\
\hline & & 7 & 0.030 & 6 \\
\hline & & & 6 & \\
\hline \multirow{2}{*}{.1.} &.$^{*}$ & 1 & 0.028 & 0.051 \\
\hline & & 8 & 7 & 4 \\
\hline \multirow[t]{3}{*}{$* 1}$. & $* \mid$. & 1 & - & - \\
\hline & & 9 & 0.056 & 0.043 \\
\hline & & & 6 & 0 \\
\hline \multirow[t]{3}{*}{.1.} & $* \mid$. & 2 & 0.031 & - \\
\hline & & 0 & 4 & 0.069 \\
\hline & & & & 1 \\
\hline \multirow[t]{2}{*}{.1.} & .1. & 2 & 0.042 & - \\
\hline & & 1 & 3 & 0.014 \\
\hline
\end{tabular}




\begin{tabular}{|c|c|c|c|c|}
\hline. &.$\left.\right|^{* *}$ & $\begin{array}{l}2 \\
2\end{array}$ & $\begin{array}{r}- \\
0.035 \\
0\end{array}$ & $\begin{array}{r}0.177 \\
0\end{array}$ \\
\hline .1. &.$\left.\right|^{*}$ & $\begin{array}{l}2 \\
3\end{array}$ & $\begin{array}{r}0.036 \\
4\end{array}$ & $\begin{array}{r}0.062 \\
5\end{array}$ \\
\hline. $\mid$ &.$\left.\right|^{*}$ & $\begin{array}{l}2 \\
4\end{array}$ & $\begin{array}{r}0.025 \\
3\end{array}$ & $\begin{array}{r}0.095 \\
1\end{array}$ \\
\hline. $\mid$ & $* \mid$ & $\begin{array}{l}2 \\
5\end{array}$ & $\begin{array}{r}- \\
0.011 \\
0 \\
\end{array}$ & $\begin{array}{r}- \\
0.041 \\
3 \\
\end{array}$ \\
\hline. $\mid$ &. $\mid$ & $\begin{array}{l}2 \\
6\end{array}$ & $\begin{array}{r}0.028 \\
0\end{array}$ & $\begin{array}{r}0.045 \\
9\end{array}$ \\
\hline .1. &.$\left.\right|^{*}$ & $\begin{array}{l}2 \\
7\end{array}$ & $\begin{array}{r}0.015 \\
5\end{array}$ & $\begin{array}{r}0.105 \\
2\end{array}$ \\
\hline .1. &.$\left.\right|^{*}$ & $\begin{array}{l}2 \\
8 \\
\end{array}$ & $\begin{array}{r}0.023 \\
0 \\
\end{array}$ & $\begin{array}{r}0.054 \\
9 \\
\end{array}$ \\
\hline. $\mid$ &. $\mid$ & $\begin{array}{l}2 \\
9\end{array}$ & $\begin{array}{r}- \\
0.012 \\
1\end{array}$ & $\begin{array}{r}0.049 \\
1\end{array}$ \\
\hline .1 &.$\left.\right|^{*}$ & $\begin{array}{l}3 \\
0 \\
\end{array}$ & $\begin{array}{r}0.007 \\
3 \\
\end{array}$ & $\begin{array}{r}0.081 \\
2 \\
\end{array}$ \\
\hline. &. $\mid$ & $\begin{array}{l}3 \\
1\end{array}$ & $\begin{array}{r}- \\
0.036 \\
3 \\
\end{array}$ & $\begin{array}{r}- \\
0.022 \\
0 \\
\end{array}$ \\
\hline. & .1. & $\begin{array}{l}3 \\
2\end{array}$ & $\begin{array}{r}0.007 \\
5\end{array}$ & $\begin{array}{r}0.020 \\
6\end{array}$ \\
\hline .1. &.$\left.\right|^{*}$ & $\begin{array}{l}3 \\
3\end{array}$ & $\begin{array}{r}0.018 \\
5\end{array}$ & $\begin{array}{r}0.122 \\
7\end{array}$ \\
\hline .1. &. $\mid * *$ & $\begin{array}{l}3 \\
4\end{array}$ & $\begin{array}{r}- \\
0.023 \\
9 \\
\end{array}$ & $\begin{array}{r}0.243 \\
9\end{array}$ \\
\hline. $\mid$ &.$\left.\right|^{*}$ & $\begin{array}{l}3 \\
5\end{array}$ & $\begin{array}{r}- \\
0.005 \\
9\end{array}$ & $\begin{array}{r}0.050 \\
5\end{array}$ \\
\hline .1. &.$\left.\right|^{*}$ & $\begin{array}{l}3 \\
6\end{array}$ & $\begin{array}{r}- \\
0.021 \\
0\end{array}$ & $\begin{array}{r}0.088 \\
3\end{array}$ \\
\hline
\end{tabular}

\begin{tabular}{|c|c|c|c|c|}
\hline Sample: 1365:01 1381:12 & & & & \\
\hline Included observations: 47 & & & & \\
\hline Correlations are asymptotical & onsistent approximations & & & \\
\hline D(DOLLAR),DNFAD(-i) & D(DOLLAR),DNFAD $(+\mathrm{i})$ & $\mathrm{i}$ & lag & lead \\
\hline.$|\cdot|$ &.$|\cdot|$ & 0 & - & - \\
\hline & & & 0.030 & 0.030 \\
\hline & & & 6 & 6 \\
\hline & . & 1 & - & - \\
\hline & & & 0.038 & 0.038 \\
\hline & & & 5 & 6 \\
\hline .1. & .1. & 2 & - & 0.035 \\
\hline & & & 0.030 & 4 \\
\hline & & & 7 & \\
\hline .1 & I. & 3 & - & 0.012 \\
\hline
\end{tabular}




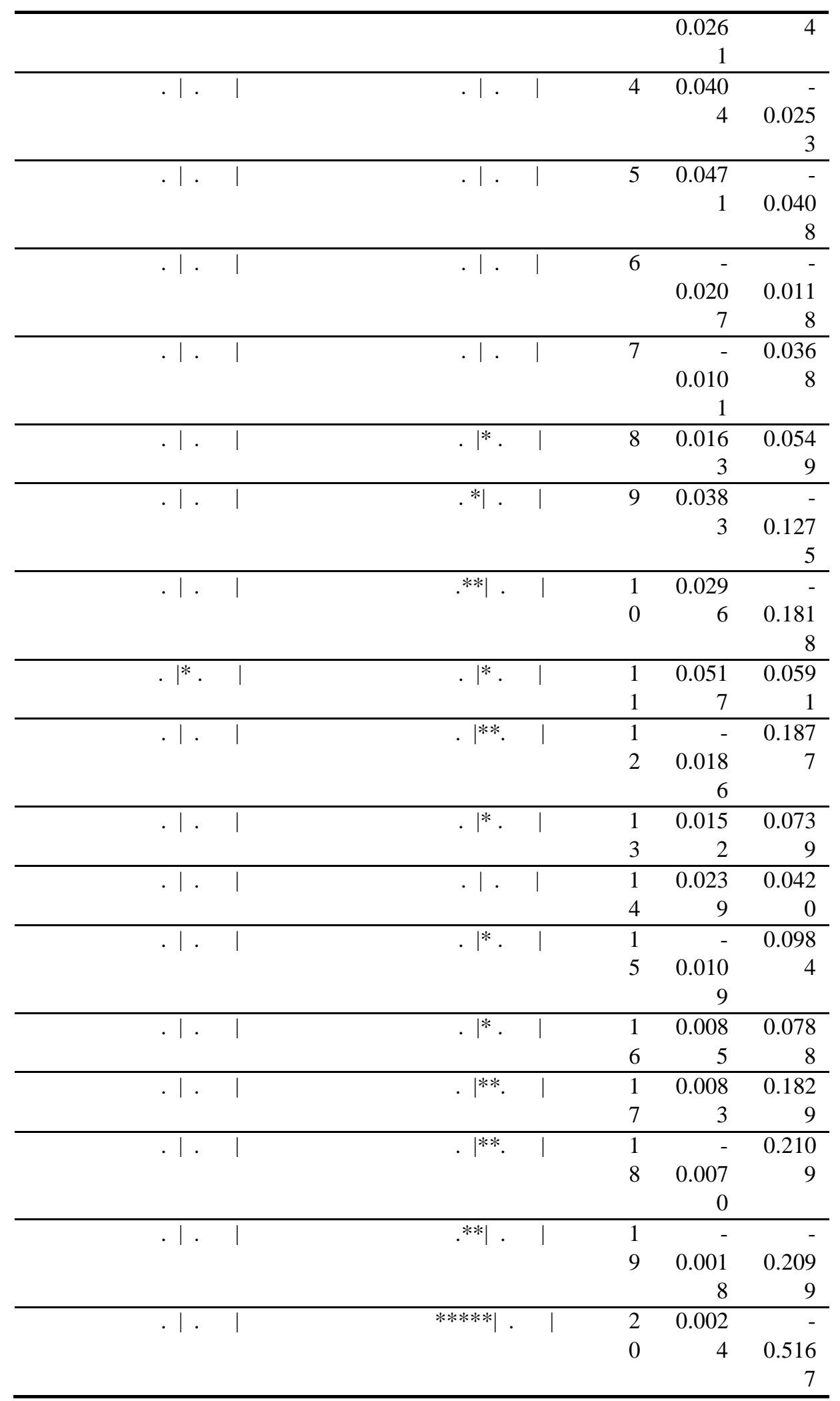




\section{Simulation}

The analysis of the long-run relationship between selling foreign exchange in the parallel market, liquidity, and cumulative balance of payments with foreign exchange is shown by a regression. This analysis, which is based upon annual data contain these variables:

$$
\begin{aligned}
& \text { Irem }=\text { the parity rate of one Dollar with Rial } \\
& \text { Irm2v = liquidity (billion Rials) } \\
& \text { Irboptd = balance of payments (million \$) } \\
& \text { Irgrdsv = sale of foreign exchange in the market (billion Rials) } \\
& \text { Ird99 = the dummy variable (equal to one in 1998) }
\end{aligned}
$$

\begin{tabular}{|c|c|c|c|c|}
\hline \multicolumn{5}{|c|}{ Dependent Variable: IREM } \\
\hline \multicolumn{5}{|c|}{ Method: Least Squares } \\
\hline \multicolumn{5}{|c|}{ Date: $05 / 17 / 04$ Time: 11:01 } \\
\hline \multicolumn{5}{|c|}{ Sample(adjusted): 19602001} \\
\hline \multicolumn{5}{|c|}{ Included observations: 42 after adjusting endpoints } \\
\hline \multicolumn{5}{|c|}{ IREM $=$ IREM(-1)+B(20011)*(IRM2V-IRM2V(-1))+B(20012)*IRBOPD } \\
\hline \multicolumn{5}{|c|}{$+\mathrm{B}(20013) *$ IRGRDSV+B(20014)*IRD99 } \\
\hline & Coefficien & Std. Error & t-Statistic & Prob. \\
\hline & $\mathrm{t}$ & & & \\
\hline $\mathrm{B}(20011)$ & 0.055541 & 0.005340 & 10.40160 & 0.0000 \\
\hline $\mathrm{B}(20012)$ & -0.032592 & 0.016491 & -1.976378 & 0.0554 \\
\hline $\mathrm{B}(20013)$ & -0.079829 & 0.008465 & -9.430504 & 0.0000 \\
\hline $\mathrm{B}(20014)$ & 1935.572 & 215.1956 & 8.994478 & 0.0000 \\
\hline R-squared & 0.993304 & Mean depe & ent var & 1455.924 \\
\hline Adjusted R-squared & 0.992775 & S.D. depen & nt var & 2421.946 \\
\hline S.E. of regression & 205.8675 & Akaike inf & riterion & 13.58274 \\
\hline Sum squared resid & 1610495. & Schwarz c & rion & 13.74823 \\
\hline Log-likelihood & -281.2374 & Durbin-W & on stat & 2.310237 \\
\hline
\end{tabular}

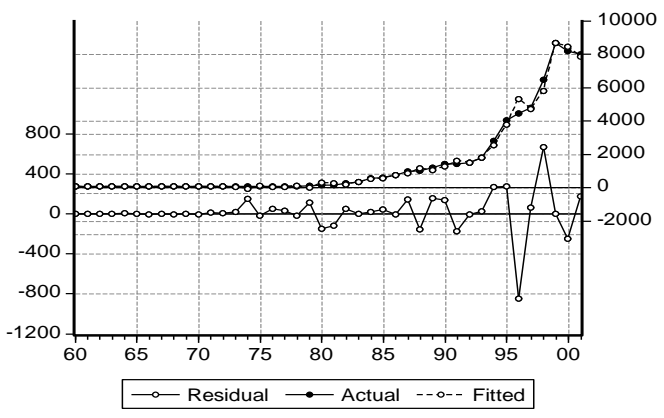

The results show that in the short run, regulating foreign exchange rate by instruments such as selling foreign exchange in the market or by controlling liquidity is not possible, but in the long run, it is possible. For further study, consider these scenarios:

Scenario 0 (baseline): solving the equation with real exogenous variables

Scenario 1: 10 percent increase in liquidity (irm $2 \mathrm{v}^{* 1.1}$ )

Scenario 2: 10 percent increase in selling foreign exchange in the market (irgdsv*1.1)

Scenario 3: one billion $\$$ increase in the balance of payments (irbopd +1000 ) 
These scenarios are defined by $0,1,2$, and 3 in the next table, which are baseline solution and other mentioned solutions, respectively. The results of dynamic simulation show that a 10 percent increase in liquidity, causes 16.7 percent increase in the foreign exchange rate and a 10 percent increase in the foreign exchange sale in the parallel market will reduce the foreign exchange rate by 6.1 percent. This simulation has been carried out for 4 years (19982001). The results are presented in the next tables and graphs.

\begin{tabular}{|c|c|c|c|c|}
\hline \multicolumn{5}{|c|}{ Baseline solution } \\
\hline & 1998 & 1999 & 2000 & 2001 \\
\hline IRBOPD & -1572 & 1845 & 6529 & 4760 \\
\hline IREM_0 (Baseline) & $\begin{array}{r}5613 . \\
4\end{array}$ & 7646.1 & 7171.1 & 6460.0 \\
\hline IRGRDSV & 6022 & 18532 & 39324 & 52445 \\
\hline IRM2V & $\begin{array}{r}16040 \\
2\end{array}$ & 192689 & 249111 & 320957 \\
\hline \multicolumn{5}{|c|}{ Scenario 1 } \\
\hline & 1998 & 1999 & 2000 & 2001 \\
\hline IRBOPD & -1572 & 1845 & 6529 & 4760 \\
\hline IREM_1 (Scenario 1) & $\begin{array}{r}6391 . \\
6\end{array}$ & 8580.9 & 8379.6 & 8017.1 \\
\hline IRGRDSV & 6022 & 18532 & 39324 & 52445 \\
\hline IRM2V_1 (Scenario 1) & $\begin{array}{r}17644 \\
2\end{array}$ & 211958 & 274022 & 353053 \\
\hline
\end{tabular}

\begin{tabular}{lrrrr}
\hline \multicolumn{5}{c}{ Scenario 2 } \\
\hline & 1998 & 1999 & 2000 & 2001 \\
\hline IRBOPD & -1572 & 1845 & 6529 & 4760 \\
\hline IREM_2 (Scenario 2) & 5566. & 7454.6 & 6672.8 & 5552.6 \\
& 5 & & & \\
\hline IRGRDSV_2 (Scenario 2) & 6624 & 20385 & 43256 & 57690 \\
\hline IRM2V & 16040 & 192689 & 249111 & 320957 \\
\hline \multicolumn{5}{c}{ Scenario 3 } \\
\hline \multicolumn{5}{c}{1998} \\
\hline IRBOPD_3 (Scenario 3) & -572 & 2845 & 7529 & 5760 \\
\hline IREM_3 (Scenario 3) & 5591. & 7601.9 & 7104.7 & 6371.5 \\
\hline \multicolumn{5}{c}{3} \\
\hline IRGRDSV & 6022 & 18532 & 39324 & 52445 \\
\hline & 16040 & 192689 & 249111 & 320957 \\
\hline
\end{tabular}

\begin{tabular}{lrrrr}
\hline \multicolumn{4}{l}{ The simulated figures of the foreign exchange rate in the three scenarios } \\
\hline & 1998 & 1999 & 2000 & 2001 \\
\hline IREM & 6468.4 & 8657.7 & 8188.1 & 8008.4 \\
\hline IREM_0 (Baseline) & 5613.4 & 7646.1 & 7171.1 & 6460.0 \\
\hline IREM_1 (Scenario 1) & 6391.6 & 8580.9 & 8379.6 & 8017.1 \\
\hline IREM_2 (Scenario 2) & 5566.5 & 7454.6 & 6672.8 & 5552.6 \\
\hline IREM_3 (Scenario 3) & 5591.3 & 7601.9 & 7104.7 & 6371.5 \\
\hline
\end{tabular}




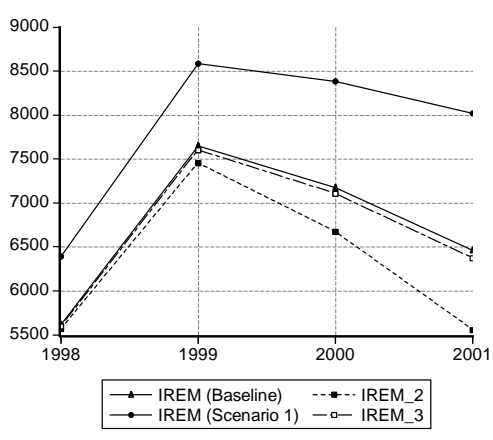

The percentage change of foreign exchange rate in the parallel market in each scenario, relative to the results of the baseline solution is shown in the following table:

\begin{tabular}{lrrrrr}
\hline & $\mathbf{1 9 9 8}$ & $\mathbf{1 9 9 9}$ & $\mathbf{2 0 0 0}$ & \multicolumn{1}{c}{ 2001 } & average \\
\hline IREM_P_CHANGE_1 (Scenario 1) & 13.9 & 12.2 & 16.9 & 24.1 & $\underline{16.7}$ \\
\hline IREM_P_CHANGE_2 (Scenario 2) & -0.8 & -2.5 & -6.9 & -14.0 & $\underline{6.0}$ \\
\hline IREM_P_CHANGE_3 (Scenario 3) & -0.39 & -0.58 & -0.93 & -1.37 & $\underline{0.8}$ \\
\hline
\end{tabular}

\section{Conclusion}

In this paper, our goal was to find out the effects of changes in Money on the foreign exchange rate in the short run and long run. In other words, we were looking to find out if we can change foreign exchange rate by changing the liquidity? On the other hand, what is the effect of the price, which has an important catalyst role in this interaction? Therefore, we looked for the triangular relationship between money, prices, and foreign exchange rate, through which we can reach foreign exchange rate control policies.

Calculations show that regulating foreign exchange rate by changing the amount of liquidity for a period of less than one year is not possible, and only the general level of prices can affect this variable. But in annual and biannual analysis, we can say that the control of the foreign exchange rate can be achieved through changes in liquidity. In other words, the long run trend of the foreign exchange rate is defined by liquidity and price level, but prices have also short term effect on the Dollar rate.

In the co-integration analysis, we checked whether the above relationships are credible for the long run or not. We concluded that:

- Liquidity affects Dollar rate in the long run

- Prices affect liquidity in the long run

- In the long run, liquidity and Dollar rate affect the price level

The long-run analysis with annual data shows that there is a significant relationship between selling foreign exchange in the parallel market. In other words, the Dollar rate is a function of the cumulative balance of payments, liquidity, and the amount of Dollar sold in the parallel market. The short-run analysis of the relationships shows that we cannot find a statistically significant relationship in this regard. In other words, there is only a long-run relationship between the variables, and there is not a clear short term relationship for them. The studies show that selling Dollars in the market with different lags have small effects on the Dollar rate in volatile directions. The same is true with the relationship of Dollar rate and liquidity. That is to say, in spite of the existence of a long run relationship between Dollar rate and liquidity, we cannot find this relationship for the short run. The same is true for the relationship between the balance of payments and liquidity in the short run.

By simulation of the amount of foreign exchange sold in the parallel market, liquidity, and cumulative balance of payments with Dollar rate, we can conclude that controlling foreign exchange rate in the short run by using tools such as selling foreign exchange in the parallel market or controlling the liquidity is not possible, but in the long run, 
by the policy of selling foreign exchange and controlling the liquidity and the balance of payments, we can control the foreign exchange market.

\section{References}

A.J. Hagger (1977) Inflation theory \& policy, Macmillan, UK.

Ammer, J., R.I. Freeman, (1995). Inflation targeting in the 1990s: the experiences of NewZealand, Canada, and the United Kingdom. Journal of Economic and Business 47: 165-192, North - Holland.

Backus, D., Driffill, J. (1985). Inflation and reputation. American Economic Review 73 (3): 530 - 538

Ball, L. (1992) Why does high inflation raise inflation uncertainty? Journal of Monetary Economics 29:371 - 388.

Belongia M. T. (1988) Are economic forecasts by government agencies biased? or Accurate?, Federal Reserve Bank of St. Louis, Review, November/December, PP-15-23.

Bidabad, Bijan [2014] General monetary equilibrium. Lap Lambert Academic Publishing, OmniScriptum GmbH \& Co. KG, ISBN: 978-3-659-54045-5, Spring 2014.

Bidabad B., and N. Kalbasi Anaraki, Inflation Targeting: Case Study of Iran, Paper prepared for the Second Hallescher workshop. http://www.bidabad.com/

Bidabad, Bijan, (2007) Triangular Causality and Controlling Parallel Exchange Market. Monetary and Banking Research Academy, Central Bank of Iran, Tehran, Iran. http://www.bidabad.com/

Broadus, J. A., JR, M. Giideriend (1996) Foreign exchange operations and the Federal Reserve, Annual report 1995.

Canzoneri M. (1985) Monetary policy games and the role of private information. American Economic Review 75 (5): 1056-1070.

Caprio, P. Honohan (1991), Monetary policy instruments for developing countries, world bank, Washington, D.C.

McNees S.K (1995) An assessment of the "official” economic forecasts, New England economic review, Federal Reserve Bank of Boston.

R- MacDonald (1988), floating Exchange rates, theories and evidence, Unwin Hyman Ltd.

Rodrik, D. (1989) Promises: Credible policy reform via signaling. Economic Journal 99: 756-772.

Taylor, J. (1982) Establishing Credibility: A rational expectation viewpoint. American Economic Review 72 (2): 81-85.

Bernanke, B.S., Laubach, T., Mishkin, F.S. and Posen A.S. (1999), “Inflation Targeting” Princeton: Princeton University Press.

Kumhof, M. (2000), "Inflation Targeting Under Imperfect Credibility” Stanford University.

Kumhof, M. Li, S. and Yan, I. (2001), "Balance of payments Crises under Inflation Targeting” Mimeo, Stanford University.

Masson, P.R., Savastano, M.A. and Sharma, S. (1997), "The Scope for Inflation Targeting in Developing Countries", IMF Working Paper WP/97/130.

Mishkin, F.S. (2000), "Inflation Targeting in Emerging Countries”, American Economic Review, vol. 90, no.2 May 2000, pp 105 - 109

Mishkin, F.S. and Schmidt-Hebbel, K. (2001) "One Decade of Inflation Targeting in the World: What Do We Know and What Do We Need to Know?", NBER 8397.

Ryan, C. and Thompson, C. (2000), "Inflation Targeting and Exchange Rate Fluctuations in Australia" Reserve Bank of Australia, Research Discussion Paper 2000-06.

Svensson, L.E.O. (1997) "Inflation Forecast Targeting: Implementing and Monitoring Inflation Targets" European Economic Review, 41 p. 1111 - 1146.

Svensson, L.E.O. (2000) “Open-Economy Inflation Targeting” Journal of International Economics 50(1) p. 155 183.

Jonas, J.; F.S.Mishkin (2003)"Inflation targeting in transition countries: experience and prospects. National Bureau of Economic Research, Working Paper 9667. April. Http://www.nber.org/papers/w9667/.

Gecchetti S.G., J. Kim (2003), Inflation targeting, price-path targeting, and output variability. National Bureau of Economic Research, Working Paper 9672. May. Http://www.nber.org/papers/w9672/.

Mishkin, F.S. (2000), Inflation targeting in emerging markets countries. National Bureau of Economic Research, Working Paper 7618. Http://www.nber.org/papers/w7618/

B. Laurence, N. Sheridan "Does Inflation Targeting Matter?" NBER, working paper 9577, March 2003.

Bernanke, B.S. and F.S. Mishkin," Inflation Targeting: A New Framework for Monetary Policy, Journal of Economic Perspectives, 1997.

Bernanke Ben S., Laubach, Thomas, Mishkin Fredric S. and Posen Adam S. " Inflation Targeting: Lessons from the 
International Experience. Princeton, NJ: Princeton University Press.

Cechetti S, and M. Ehrmann "Does Inflation Targeting Increase Output Volatility? An International Comparison of Policymakers preferences and Outcomes", Central Bank of Chile, working paper 69, April 2000. http://www.bcentral.c1/Estudios/DTBC/69/dtbc69.pdf

Cecchetti Stephen G. and Junhan Kim, "Inflation Targeting, Price-Path Targeting, and Output Variability", NBER working paper 9672, May 2003.

Christiano, Lawrence J., Martin Eichenbaum; Charles L. Evans, "Identification of the Effects of Monetary Policy Shocks," in M.I. Blejer et al. eds, Financial Factors in Economic Stabilization and Growth. New York, Cambridge University Press, 1996.

Ditmar R., Gavin, W.T, and F.E. kydland "What Do New-Keynesian Phillips Curves Imply for Price Level targeting, Review, Federal Reserve Bank of St. Louis 2000.

Estrella Arturo and Frederic S. Mishkin "Is There a Role for Monetary Aggregates in the Conduct of Monetary Policy", Journal of Monetary Economics, October 1997.

Feldstein, M. "The Costs and benefits of Price Stability", NBER working paper 6200, Sept. 1997.

Friedman, Benjamin M., "The Use and Meaning of Words in Central Banking: Inflation Targeting, Credibility, and Transparency, NBER working paper 8972, June 2002.

Jonas. Jiri, and Frederic S. Mishkin "Inflation Targeting in Transition Countries: Experience and Prospects, NBER working paper 9667, April 2003.

King, M., "Challenges for Monetary Policy: New and Old", in New Challenges for Monetary Policy, Federal Reserve Bank of Kansas City, Kansas City, Missouri, 1999.

Masson Paul, R., Savastano, Miguel A.; Sharma Sunil. "The Scope for Inflation Targeting in Developing Countries, IMF working paper 130, October 1997.

McCallum Bennett T., "Inflation Targeting in Canada, New Zealand, Sweden, The United Kingdom, And In General", NBER working paper 5579, May 1996.

McCallum Bennett T., "Specification of Policy Rules and performance Measure in Multicountry Simulation Studies, Journal of International Money and Finance, June 1994.

Mishkin Frederic S., "Inflation Targeting in Emerging Market Countries", American Econ. Rev., May 2000.

Mishkin Frederic S., "Issues in Inflation Targeting "in Price Stability and the Long-run Target for Monetary Policy, Bank of Canada, Ottawa, Canada, 2001.

Mishkin Frederic S. "International Experiences with Different Monetary Regimes", Journal of Monetary Economics, 43, 1999.

Mishkin Frederic S., "International Experiences With different Monetary Policy Regimes," Journal of Monetary Economics, Vol 43, 1999.

Mishkin Frederic S, and Posen, Adam S. "Inflation Targeting: Lessons from Four Countries", Federal Reserve Bank of New York, Economic Policy Review, August 1997.

Mishkin Frederic S., and Klaus Schmidt-Hebbel "One Decade of Inflation Targeting in the World: What Do We Know and What Do We Need to Know", NBER working paper 8397, July 2001.

Svensson Lars, E.O., The Swedish Experience of an Inflation Target, NBER working paper 4985, Jan 1995.

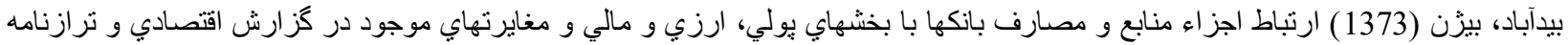

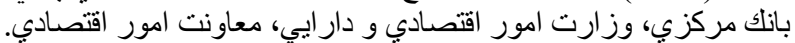

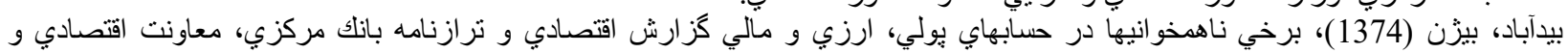

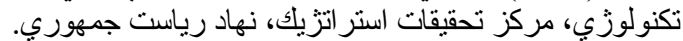

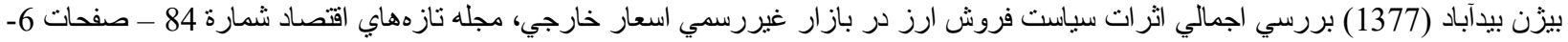

$$
\begin{aligned}
& \text { 4. يُّو هشكدة بولي و بانكي، بانك مركزي ايران. }
\end{aligned}
$$


بيزّن بيدآباد (1374) امنيت اقتصادي و مروري بر مو انع سرمايهكناري در ايران، مركز يزّو هشهاي مجلس شوراي اسلامي.

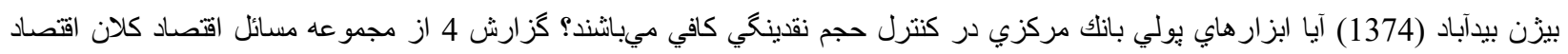
ايران، مركز تحقيقات استر انزيك نهاد رياست جمهوري.

بيزن بيدآباد (1374) آيا تورم در ايران به غير از افز ايش حجم نقدينكي علت اساسي ديكري نيز دارد، كزارش شماره 3 از مجمو عه مسائل اقتصاد كلان، مركز تحقيقات استر اتزيك نهاد رياست آنس جمهوري.

بيزن بيدآباد (1374) آيا كاهش تورم در اثر كاهش رشد نقدينكي سبب كاهش رشد اقتصادي در ايران ميشود؟ كز ارش شمارة 2 از مجموعة مسائل

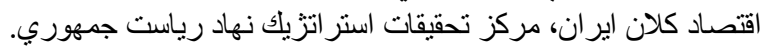

بيزن بيدآباد (1375) الكوي اقتصاد سنجي كلان اير ان، مؤسسه تحقيقات يولي و بانكي، بانك مركزي ايران. وير ايش 4.

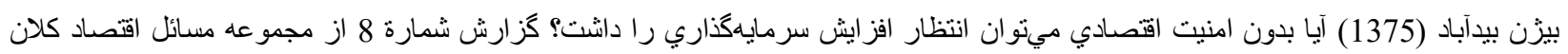
اير ان، مركز تحقيقات استر اتزيك نهاد رياست جمهورئ

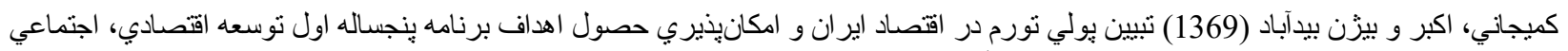

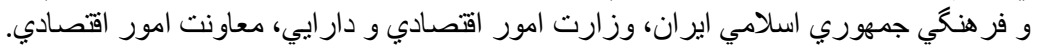

كميجاني، اكبر و بيزن بيدآباد (1370) سياستهاي يولي مناسب جهت تثييت فعاليتهاي اقتصادي در ايران، طرح تحقيقاتي مرحله اول وزارت امور

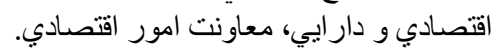

كميجاني، اكبر و بيزّن بيدآباد (1371) سياستهاي يولي و ارزي مناسب جهت تثبيت فعاليتهاب اقتصادي در ايران، طرح تحقيقاتي مرحله دوم، وزارت

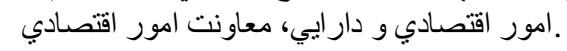

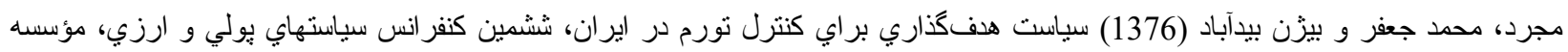
تحقيقات يولي و بانكي، بانك مركزي جمهوري استلامي ايران.

\section{Copyrights}

Copyright for this article is retained by the author(s), with first publication rights granted to the journal. This is an open-access article distributed under the terms and conditions of the Creative Commons Attribution license (http://creativecommons.org/licenses/by/4.0/). 